Article

\title{
Surface Velocity Analysis of Surge Region of Karayaylak Glacier from 2014 to 2020 in the Pamir Plateau
}

\author{
Yanfei Peng ${ }^{1}(\mathbb{D})$, Zhongqin Li ${ }^{1,2, *}$, Chunhai Xu ${ }^{2,3}$, Hui Zhang ${ }^{2}$ and Weixiao Han ${ }^{4,5}$ \\ 1 College of Geography and Environmental Science, Northwest Normal University, Lanzhou 730070, China; \\ 2019212427@nwnu.edu.cn \\ 2 State Key Laboratory of Cryospheric Sciences/Tien Shan Glaciological Station, Northwest Institute of \\ Eco-Environment and Resources, Chinese Academy of Science, Lanzhou 730000, China; \\ xuchunhai@lzb.ac.cn (C.X.); zhanghui@lzb.ac.cn (H.Z.) \\ 3 National Cryosphere Desert Center, Northwest Institute of Eco-Environment and Resources, \\ Chinese Academy of Science, Lanzhou 730000, China \\ 4 Key Laboratory of Remote Sensing of Gansu Province/Heihe Remote Sensing Experimental Research Station, \\ Northwest Institute of Eco-Environment and Resources, Chinese Academy of Science, \\ Lanzhou 730000, China; weixiaohan@lzb.ac.cn \\ 5 University of Chinese Academy of Science, Beijing 100049, China \\ * Correspondence: lizq@lzb.ac.cn
}

Citation: Peng, Y.; Li, Z.; Xu, C.; Zhang, H.; Han, W. Surface Velocity Analysis of Surge Region of Karayaylak Glacier from 2014 to 2020 in the Pamir Plateau. Remote Sens. 2021, 13, 774. https://doi.org/ $10.3390 / \mathrm{rs} 13040774$

Academic Editor: Gareth Rees

Received: 5 January 2021

Accepted: 16 February 2021

Published: 20 February 2021

Publisher's Note: MDPI stays neutral with regard to jurisdictional claims in published maps and institutional affiliations.

Copyright: (c) 2021 by the authors Licensee MDPI, Basel, Switzerland. This article is an open access article distributed under the terms and conditions of the Creative Commons Attribution (CC BY) license (https:/ / creativecommons.org/licenses/by/ $4.0 /)$.

\begin{abstract}
The west branch of Karayaylak Glacier (eastern Pamir Plateau) surged in May 2015, significantly impacting on local socio-economic development. This event was also of great significance for studies of surging glaciers. Using Sentinel-1 imagery analyzed by offset tracking, based on normalized cross-correlation (NCC), and with the support of the Google Earth Engine (GEE) platform, we quantified the ice surface velocity of the west branch and terminus of Karayaylak Glacier from 13 October 2014 to 17 October 2020. Sentinel-1 images were acquired at intervals of 12 or 24 days. We also used a three-dimensional (3-D) laser scanner to measure the velocity of 3 ablation stakes and 56 feature points in the study region from 15 August to 6 October 2015, for the purpose of accuracy assessment. We set up an automatic meteorological station to record the air temperature in the same period and combined this with data from Tashkurgan meteorological station from 1957 to 2015. Analysis of this dataset provided insights into the glacier surge mechanism, with the following conclusions. (1) Surface velocity of the west branch and terminus of Karayaylak Glacier increased sharply after October 2014. The velocity then dropped significantly in the two months after the surge, and stayed at low values for nearly a year. After 2017, the velocity was slightly higher than in the previous period. (2) The surge event occurred from 11 April to 17 May 2015; the average surface velocity in this phase attained $2395 \mathrm{~m} \mathrm{a}^{-1}$ with a maximum velocity of $4265 \mathrm{~m} \mathrm{a}^{-1}$ at the west branch terminus. (3) From 2017 to 2020, the velocity showed periodic annual changes. (4) Based on the meteorological data analysis, we conclude that this surge resulted from the interaction between thermal and hydrological control mechanisms. Simultaneously, we demonstrate the high potential of the GEE platform and Sentinel-1 data to extract glacier surface velocity.
\end{abstract}

Keywords: Karayaylak glacier; surge glacier; glacier surface velocity; Google Earth Engine; Sentinel1; offset tracking

\section{Introduction}

The Tibetan Plateau and surrounding mountains represent the world's largest glacierized area outside of Alaska and the Arctic, Antarctic, and Greenland [1,2]. Research on the Pamir-Karakoram-Himalaya mountain glaciers has included studies of glacier length and area (the latter exceeds $70,000 \mathrm{~km}^{2}$ [3]), debris cover [4,5], mass balance [6-9] and glacier impact on climate change and sea-level $[1,10]$. This region is also regarded as one of the most active surge zones [11,12]. Glacier surges are usually defined as quasi-periodic advances or increases in flow velocity unrelated to external triggers $[13,14]$. Surging glaciers 
typically undergo quasi-cyclic oscillations between shorter active phases (days to decades) and longer quiescent phases $[13,15,16]$, with flow speeds in the surge period reaching 10-1000 times those in the quiescent phases [16]. On the Pamir Plateau 206 spatially surges within 186 glacier bodies were identified from 1988 to 2018 [17], which were much more than the 51 glacier surges from 1988 to 2006 [18]. Karayaylak Glacier is located on the northern side of Kongur Tagh, one of the two main summits of the Eastern Pamir Plateau. Studies have reported that the west branch of the Karayaylak Glacier surged in May 2015 [19-21]. The glacier's surface velocity in the surge phase reached 10-100 times that in quiescent phases, and its terminus advanced over grassland and houses [22]. This incident was published by the Chinese news media [23], due to its significant impact on local socio-economic development, and was also of great significance to studies of surge-type glaciers.

The glacier surges show a wide range of possibilities to characterize its frontal advances (or not), surge duration and velocity and the interactions between the tributary and main glacier $[24,25]$. The Karakoram glaciers received considerable scientific attention due to the abnormal mass balance [26] and many typical surges [27]. The eastern Pamir Plateau, along with the nearby Karakoram, is regarded as a transition from positive to negative mass balance [28]. Some studies have recently been published to reveal the specific glacier dynamic characteristic [29] and surging glacier distribution [17] in this region. These surges are dominated by the large-sized glacier and the highly variable surge timing and duration [17]. The number of surge events from 1988 to 2018 was unexpectedly higher than of the Karakoram [17]. However, the typical glacier surges in the eastern Pamir still received less attention $[17,30]$.

The application of remote-sensing technology in glaciology permits identification of without debris-covered glacier ice [31,32] and glacier debris [33-35], as well as glacier mass balance monitoring [6,36,37], extraction of glacial dynamic factors, and others. In particular, glacier velocity is a factor of great significance to the redistribution of glacier mass and energy [38,39] and can be used to monitor glacier surging [25]. The estimation of glacier velocity with remote sensing usually employs speckle and/or feature tracking, Synthetic Aperture Radar Interferometry (InSAR) and Differential Synthetic Aperture Radar Interferometry (DInSAR) methods. Over the past two decades, the capabilities of InSAR for detecting and quantifying the surface deformation with a precision in the order of millimeters have been well demonstrated [40]. Therefore, these two methods are widely applied to ice flow speed monitoring [41-45]. However, the low coherence and non-steady deformation processes are two main problems for retrieving accurate phase deformation using InSAR [40]. Feature tracking methods are generally based on repeat optical satellite and synthetic aperture radar (SAR) satellite imagery, typically referred to as image matching in the optical domain and offset-tracking in the microwave domain [46]. Image matching is usually based on normalized cross-correlation (NCC) in the spatial domain [46-49], and has been gradually developed on the basis of different normalizations and correlation algorithms in the frequency domain. T. Heid compared the above methods over five regions of the world with different representative glacier characteristics, finding that cross-correlation operated in the frequency domain using the fast Fourier transform on orientated images outperformed the other Fourier methods with different normalizations. However, NCC performs well on narrow glaciers where small window sizes are needed [50].

One example of an image-matching algorithm with optical imagery is Global Land Ice Velocity Extraction from Landsat 8 (GoLIVE), which is a compilation of ice velocity mappings generated from pairs of Landsat 8 panchromatic images. This dataset covers all terrestrial permanent ice within the latitude range $82^{\circ} \mathrm{S}$ to $82^{\circ} \mathrm{N}$ that is larger than $5 \mathrm{~km}^{2}$ in area, from May 2013 to the present. Velocity vector grids are generated at a sample spacing of $300 \mathrm{~m}$ from small sub-images that are either $300 \mathrm{~m}$ or $600 \mathrm{~m}$ in extent, depending on the region [51]. Image matching based on optical satellite imagery for monitoring glacier velocity is widely used $[47,48,51]$; However, optical satellite imagery cannot always enable 
continuous time series, due to cloudy conditions, especially in high mountain and cold regions. Radar remote-sensing technology can penetrate clouds and is, therefore, useful in all weather conditions. It has also been proven advantageous in rugged mountain areas with complex topography $[52,53]$.

Offset-tracking procedures are usually adopted in deformation monitoring with longer time intervals, or glacier analysis with rapid changes [54-56]. Strozzi implemented two complementary offset-tracking methods in 2002: intensity and coherence tracking, and compared their respective results to DInSAR, finding offset tracking can be an alternative when the loss of coherence limits DInSAR [53]. In the NCC-based offset-tracking algorithm for displacement measurement, the search window size is a key factor affecting the magnitude of displacement. Huang et al. proposed the average velocity gradient (AVG) method to optimize window size for the locally adaptive flow field [57]. Many research works have been devoted to glacier surface velocity monitoring using the offset-tracking method $[58,59]$. Wendt et al. calculated the velocity of Bivachny Glacier (Pamir Plateau) from 2011 to 2015 using a combination of optical and SAR imagery, including the velocity during the surge phase in 2014 [60]; Paul et al. studied the surge of Hispar Glacier (Karakoram) in 2015 based on offset-tracking with repeat optical images, and obtained the flow speed from 2015 to 2016 [25]. The above research is all based on early SAR images that have short time series which do not continue beyond the surge phase. Ground-based measurements of glacier surface velocity are also absent from these studies, which means there is no guarantee of accuracy.

Sentinel-1/2 images are available from 2014 onwards and have become well suited to glacier research in recent years because of their high spatio-temporal resolution $[61,62]$. We also note that the studies noted above used Windows-based software such as GAMMA and COSI-Corr, which are time-consuming and labor-intensive for large SAR data processing tasks, thus restricting the acquisition of long-term, continuous time series [63]. The emergence of cloud data processing platforms in recent years has largely solved this issue: for example, the Pleiades supercomputer provided by National Aeronautics and Space Administration (NASA) Earth Exchange (NEX) [64], Amazon Web Services (AWS) [65] and Google Earth Engine (GEE). GEE combines a multi-petabyte catalog of satellite imagery and geospatial datasets with planetary-scale analysis capabilities $[63,66]$, and has been widely applied to the remote-sensing [67-70] (including glacier remote sensing [70]) domain due to its powerful functions and convenient acquisition.

Given the advantages of the GEE platform, this study derived a continuous surface velocity time series of the surge region of Karayaylak Glacier, from 2014 to 2020, using offset-tracking with repeat Sentinel-1 images. This paper continues with a brief presentation of the study region. The method and data section illustrates the techniques used in the study and provides details about remote-sensing data and ground-based measurement data. The results and uncertainty analysis are presented in the subsequent section. Finally, after presenting and discussing the data from the automatic meteorological station and Tashkurgan meteorological station; this paper finishes with some conclusions about the surge mechanism.

\section{Study Region}

The Pamir Plateau $\left(38^{\circ} \mathrm{N}-41^{\circ} \mathrm{N} ; 73^{\circ} \mathrm{E}-76^{\circ} \mathrm{E}\right)$ is located in Central Asia, bordering the Taklamakan Desert to the east and the Karakoram region to the south, and lies partly in Kyrgyzstan, Tajikistan, Afghanistan, and China. About 10,234 glaciers are distributed across the Pamir Plateau, with a total area of about 10,500 $\mathrm{km}^{2}$ [3]. Glacier resources in the Pamir Mountains, like in the other main mountain ranges in Central Asia, play an important role in modifying river run-off characteristics, particularly in sustaining summer river flows [71,72]. The part of the Pamir Plateau in Chinese territory is known as the Eastern Pamir Plateau (Figure 1a). The average elevation of the Eastern Pamir Plateau is more than 3000 m a.s.l. Muztagh Ata (7509 m a.s.l.) and Kongur Tagh (7649 m a.s.l.) are the two main summits in the region. 


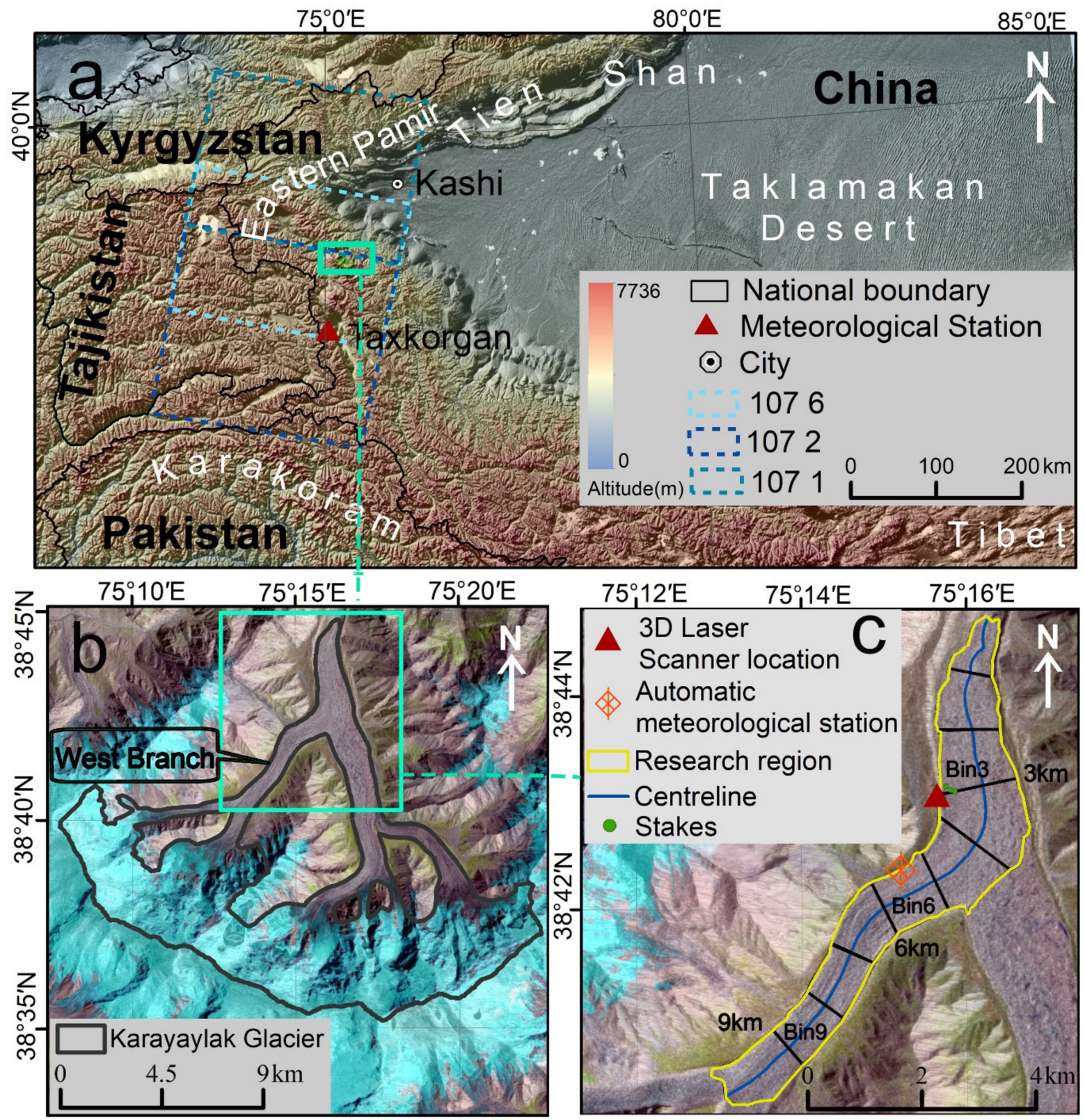

Figure 1. Panels (a,b) show Karayaylak Glacier's location and the strip of Sentinel-1 imagery in this study. The two numbers of the panel (a)'s legend represent "relative orbit number" and "slice number" of imagery. Panel (c) shows the velocity research region of Karayaylak glacier in this work and the locations of the 3D laser scanner and automatic meteorological station in the field investigation. Ten sub-regions separated at $1 \mathrm{~km}$ equidistance along the centreline are shown in panel (c). The Landsat 8 image at 2020/8/16 and National Aeronautics and Space Administration (NASA) Shuttle Rader Topography Mission (SRTM) digital elevation model (DEM) acted as the base map.

Karayaylak Glacier $\left(38.7^{\circ} \mathrm{N}, 75.2^{\circ} \mathrm{E}\right)$, on the northern side of Kongur Tagh in Xinjiang, China (Figure $1 \mathrm{~b}$ ), covers $115.2 \mathrm{~km}^{2}$ (of which, $25.6 \mathrm{~km}^{2}$ is debris-covered), and has a full length of $20 \mathrm{~km}$ [73]. The glacier consists of east and west branches, and lies at an altitude of 2800-7649 m a.s.l. Observations of Karayaylak Glacier's mass balance based on a digital elevation model (DEM) showed a loss of $0.32 \pm 0.19 \mathrm{~m}$ water equivalent (w.e.) $\mathrm{a}^{-1}$ (a means one year) between 1971-1976, but a gain of $0.37 \pm 0.25 \mathrm{~m}$ w.e. $\mathrm{a}^{-1}$ between 1999-2013/14 [74]. The west branch of this glacier surged in May 2015. This research focuses on the velocity of the west branch and the terminus (Figure 1c). The centre-line of the west branch and terminus are shown in Figure 1c. This branch has a total length of $10.65 \mathrm{~km}$ and is divided into $1 \mathrm{~km}$ subregions. 


\section{Data}

We employed multisource satellite data as well as ground-based measurements. Images acquired by Sentinel- 1 were used for the surface velocity retrieval. Landsat- 8 and Sentinel-2 images were employed to analyze spatial changes of surge velocity and the glacier extent. Additionally, the GoLIVE dataset and the second Chinese Glacier Inventory provided indispensable references. We conducted three periods of fieldwork at Karayaylak Glacier after the surge in May 2015, during which times the surface velocity was obtained by 3D laser scanner and meteorological data were collected from an automatic meteorological station, for accuracy assessment and surge mechanism analysis.

\subsection{Remote-Sensing Data}

We selected 292 Interferometric Wide swath (IW), VV polarization Sentinel-1 Level-1 ground range-detected (GRD) images [61]. Sentinel-1 GRD images covering Karayaylak Glacier are available from 8 October 2014. As shown in Table 1, we filtered images according to "relative orbit number" and "slice number" under the premise of restricting the study region (Figure 1). Further research on velocity in the surge phase required a single image covering the study region and a combination of two scenes to shorten the interval to 12 days from 30 March to 6 October 2015.

Table 1. The information of data used in this study. Due to the different satellite-based on different satellite orbit coordinate system, we ascertain the location of Sentinel-1 ground range-detected (GRD), Landsat 8 and Sentinel-2 images by" relativeOrbitNumber and sliceNumber"," WRS_PATH \& WRS_ROW" and "SENING_ORBIT_NUMBER \& MGRS_TILE" respectively.

\begin{tabular}{|c|c|c|c|c|c|c|}
\hline \multirow[t]{2}{*}{ Platform } & \multirow[t]{2}{*}{ Time } & \multicolumn{2}{|c|}{ Strip Number } & \multirow[t]{2}{*}{$\begin{array}{c}\text { Repeat Cycle } \\
\text { [day] }\end{array}$} & \multirow[t]{2}{*}{$\begin{array}{c}\text { Resolution } \\
{[\mathrm{m}]}\end{array}$} & \multirow[t]{2}{*}{ Count } \\
\hline & & relativeOrbitNumber & sliceNumber & & & \\
\hline Sentinel-1GRD & $\begin{array}{l}2014 / 10 / 13- \\
2016 / 12 / 19\end{array}$ & 107 & 6 & 24 & 10 & 70 \\
\hline Sentinel-1GRD & $\begin{array}{l}2017 / 01 / 12- \\
2020 / 10 / 05\end{array}$ & 107 & 6 & 12 & 10 & 214 \\
\hline & $2015 / 03 / 30-$ & 107 & 1 & 12 & 10 & 10 \\
\hline Sentinel-1GRD & $2015 / 06 / 10$ & 107 & 2 & 12 & 10 & 10 \\
\hline Sentinel-1GRD & $\begin{array}{c}2016 / 09 / 20-10 / 08 \& \\
2017 / 02 / 05-02 / 23\end{array}$ & 107 & 6 & 18 & 10 & $2^{1}$ \\
\hline \multirow[t]{2}{*}{ Sentinel-1GRD } & $2015 / 10 / 15$ & 34 & 7 & - & 10 & $1^{2}$ \\
\hline & & WRS_PATH & WRS_ROW & & & \\
\hline Landsat 8 & $2015 / 04 / 13$ & 150 & 33 & - & 30 & 1 \\
\hline Landsat 8 & $2015 / 05 / 08$ & 149 & 33 & - & 30 & 1 \\
\hline Landsat 8 & $2015 / 05 / 15$ & 150 & 33 & - & 30 & 1 \\
\hline Landsat 8 & $2015 / 07 / 11$ & 149 & 33 & - & 30 & 1 \\
\hline \multirow[t]{2}{*}{ GoLIVE } & $2014 / 09 / 12-2020 / 5 / 30$ & 149 & 33 & $16 / 32 / 48$ & 300 & 158 \\
\hline & & SENING_ORBIT_NUM & MGRS_TILE & & & \\
\hline Sentinel-2 & $2016 / 09 / 18$ & 48 & 43SEC & - & $10 / 20^{3}$ & 1 \\
\hline
\end{tabular}

${ }^{1}$ In the image pairs obtained according to the filtering conditions in this study, the interval of 18 only appeared twice. ${ }^{2}$ Due to the acquisition date of the image with this strip is more close to the field investigation date, so this image is selected for verification with field data and only use once in the study. ${ }^{3}$ This paper uses Band 4 (central wavelength: $0.664 \mu \mathrm{m}$ ), Band 8 (central wavelength: $0.83 \mu \mathrm{m}$ ) and Band 11 (central wavelength: $1.613 \mu \mathrm{m}$ ) of Sentinel-2 images, the spatial resolution of B4 and B8 is $10 \mathrm{~m}$ and of B11 is $20 \mathrm{~m}$.

This paper utilizes cloudless Landsat 8 images covering the study region to analyze glacier morphological variations during the surge phase. Due to the limitation of image quality, the Sentinel-2 image on 18 September 2016, was selected to extract the margin of the west branch and terminus of Karayaylak glacier. The Global Land Ice Velocity Extraction from Landsat 8 (GoLIVE), distributed via the National Snow and Ice Data Center, was used as a reference for glacier velocity and for choosing parameters in the velocity extraction. This dataset generates a normalized cross-correlation surface to determine the best match using Landsat 8 panchromatic images, thus yielding global glacier velocities, with accuracy range of $\sim 1 \mathrm{~m} /$ day to $\sim 0.02 \mathrm{~m} /$ day $\pm 5 \mathrm{~m}$ and a spatial resolution of $300 \mathrm{~m}$ [51]. 


\subsection{Ground-Based Measurement Data}

The dynamic behavior of the surge in 2015 was further observed during three field visits to the Karayaylak Glacier from 16 to 20 May, 14 to 20 August, and 4 to 7 October, 2015. The purpose of the first visit was to obtain first-hand field material after the surge; the second and third visits were used to support the research program. The specific observation aims were to (1) locate the terminus and margin of the surge region of Karayaylak Glacier, using the real-time kinematic (RTK) method based on the Global Navigation Satellite System (GNSS); (2) obtain the glacier flow speed by scanning the surge region and stagnant ice distributed in lateral moraines using a 3D Laser scanner; (3) install ablation stakes on the glacier surface to monitor glacier ablation; (4) collect continuous observations of air temperature and precipitation at Karayaylak Glacier, by setting up an automatic meteorological station (Figure 1c) at the central glacier (altitude $3398 \mathrm{~m}$ a.s.l.). The present study uses the field-measured ice flow speed and the air temperatures from the automatic meteorological station.

The 3D laser radar technique quantitatively measures glacier velocity and the characteristics of ice surface landforms such as drumlins, moraines and debris by establishing a high-resolution DEM and quantifying its changes. The specific method is as follows. (1) Perform coordinate system correction, data merging, and point cloud data filtering to obtain a 3D point cloud data from two field scans; (2) obtain a high-resolution DEM of processed scanning data through the RiSCAN PRO 1.81 software. We can obtain the surface morphological characteristics by analyzing the same region in two DEMs, usually with a high spatial resolution $(0.1 \mathrm{~m})$. Here we used a Riegl VZ-6000, which is the latest V-series 3D laser scanner launched by RIEGL Laser Measurement Systems in Austria. The accuracy of this type of survey has been reported to be within $15 \mathrm{~mm}$ and $10 \mathrm{~mm}$ for repeated surveys provide that the degree of conformity of a measured quantity to its actual (true) value [75].

After detailed exploration of Karayaylak Glacier and its surrounding terrain, we set up a fixed GPS control point $\left(38^{\circ} 43^{\prime} 9.077^{\prime \prime} \mathrm{N}, 75^{\circ} 15^{\prime} 38.065^{\prime \prime} \mathrm{E}, 3235 \mathrm{~m}\right.$ a.s.l.) on a lateral moraine at the intersection of the west and east branches. This was used as a datum point for the 3D laser scanner (Figure 1c). We also installed three ablation stakes (Figure 1c) at the edge of glacier terminus to monitor glacier velocity. We conducted the scan using the 3D laser scanner at the datum point on 8 August 2015, and carried out a repeat scan on 6 October. We selected 56 feature points from the 3D point cloud to calculate the velocity, thus obtaining the daily average velocity of 3 stakes and 56 feature points in total.

The high-performance portable automatic meteorological station installed in the field was a Davis Vantage Pro (Davis Instruments, USA). The instrument has an air temperature range of $-40{ }^{\circ} \mathrm{C}$ to $65^{\circ} \mathrm{C}$ with a resolution of $0.1^{\circ} \mathrm{C}$ and accuracy of $0.5^{\circ} \mathrm{C}$ [76].

\section{Methods}

\subsection{Surface Velocities Retrieval}

Glacier velocity was calculated using offset-tracking based on SAR intensity images. The offset-tracking method obtains the displacement between two SAR images, according to the offset of feature points in the search areas of a reference image and search image in a specific pattern-matching algorithm. The NCC [77] algorithm is widely used due to its simplicity and reliability. First, NCC calculates the correlation coefficient between a template in the first image (reference image) and subset (template) of the same size in the second image (search image). It then considers the pixel which produces the maximum correlation coefficient as the best matching in this template [78]. The correlation coefficient CC is calculated by formula (1):

$$
C C(i, j)=\frac{\sum_{k, l}\left(s(i+k, j+l)-\mu_{s}\right)\left(r(k, l)-\mu_{r}\right)}{\sqrt{\sum_{k, l}\left(s(i+k, j+l)-\mu_{s}\right)^{2} \sum_{k, l}\left(r(k, l)-\mu_{r}\right)^{2}}}
$$


where $(i, j)$ indicate the position in the search area, $(k, l)$ the position in the reference area, $\mathrm{r}$ the pixel value of the reference template, $\mathrm{s}$ the pixel value of the search template, $\mu_{r}$ the average pixel value of the reference template and $\mu_{s}$ the average pixel value of the search template. It can be seen that the size of the search window is a crucial factor in NCC. The search window can contain one feature point and its neighboring pixels. This entity should become unique; thus, the ideal situation would be to find a match for every pixel independently, which is not practically feasible [78]. The search windows should be big enough to ensure that texture (and not noise) is matched, but small enough to limit displacement gradients within the window. A small window size is useful in some cases, for example shear zones or where glaciers flow over obstacles, and for small glaciers [50]. Therefore, this section tests different window sizes to identify the optimal matching. The matching result is considered to be optimized when assumed correct matches are obtained over most glacierized areas, without increasing the window size. Meanwhile, the greatest distance a pixel may shift is another parameter needed for the displacement estimation of GEE. Thus, the GoLIVE data from 2014-2020 were downloaded and converted to Tagged Image File Format (TIFF) in batches (using the Python programming language), to extract the maximum displacement of the glacier in different periods. The maximum shift and window size are considered as two input parameters to calculate the displacement.

We used the Google Earth Engine to (1) transfer and mosaic images, (2) call the "Crosscorrelation" function for NCC performance, and (3) separate glaciers and export the tables and images along with the displacements. The above process was integrated into one GEE file, which automatically calculates displacement estimates for 140 image pairs in total. The processing methodology of GEE is presented in Figure 2. First, we filtered Sentinel-1 GRD images by region and period, then mosaicked images with "relative orbit number" and "slice number" of "107, 1" and "107, 2", respectively, from 30 March to 10 June 2015. Second, we calculated the displacement of the Sentinel-1 GRD images covering the study region by the "Cross-correlation" algorithm, which is provided by GEE and requires the input parameters of window size and the most significant distance a pixel may shift. Due to the considerable differences in displacements during the surge, quiescence and build-up phases, we ascertained the above parameters separately for various glacier stages (Table 2), with GoLIVE data as a reference. The "Cross-correlation" function outputs an image composed of four bands of information. The first three bands are distances: the horizontal and vertical displacements, and the Euclidean distance for each pixel in the first image to the pixel which has the highest corresponding correlation coefficient in the second image. The fourth band is the value of the correlation coefficient for that pixel. In the third step, we separated the study area into 10 bins at $1 \mathrm{~km}$ resolution along the centre-line of the west branch and terminus of Karayaylak Glacier. We then exported the mean displacement within each bin and the "Cross-correlation" function's output image. The margin of Karayaylak glacier is based on the second Chinese Glacier Inventory [73] and manual correction using Sentinel-2 images.

\subsection{Accuracy Assessment of Surface Velocities}

The accuracy of the velocity retrieval depends on the Google Earth Engine data processing and cross-correlation quality. We assess the correlation quality in this section. The accuracy of the cross correlation depends on the image quality, glacier surface characteristics and its spatial representation, co-registration error, and geocoding [58]. These influences are difficult to quantify or measure. Similar to previous studies $[25,59,60]$, we calculated the displacement of a stable area adjacent to the glacier to estimate uncertainties in the velocity derived from different image orbits with varying time intervals. After distinguishing the non-glacier area using the Randolph Glacier Inventory 6.0 (RGI 6.0) [79], we produced 1000 randomly distributed samples over stable ground (Figure 3), then calculated the mean velocity and standard deviation $(1 \sigma)$ of these samples (Table 3 ). 
Table 2. Window size and max gap (the greatest distance a pixel may shift in either vertical or horizontal) of cross-correlation in the different phases.

\begin{tabular}{ccc}
\hline Period & Window Size (pixel) & Max Gap (pixel) \\
\hline $2014 / 10 / 13-2015 / 03 / 30$ & 7 & 15 \\
$2015 / 03 / 30-2015 / 07 / 28$ & 41 & 61 \\
$2015 / 07 / 28-2020 / 10 / 17$ & 5 & 15 \\
$2015 / 8 / 21-2015 / 10 / 15^{1}$ & 7 & 35 \\
\hline
\end{tabular}

${ }^{1}$ This image pair is used to verification with data of field measurement.

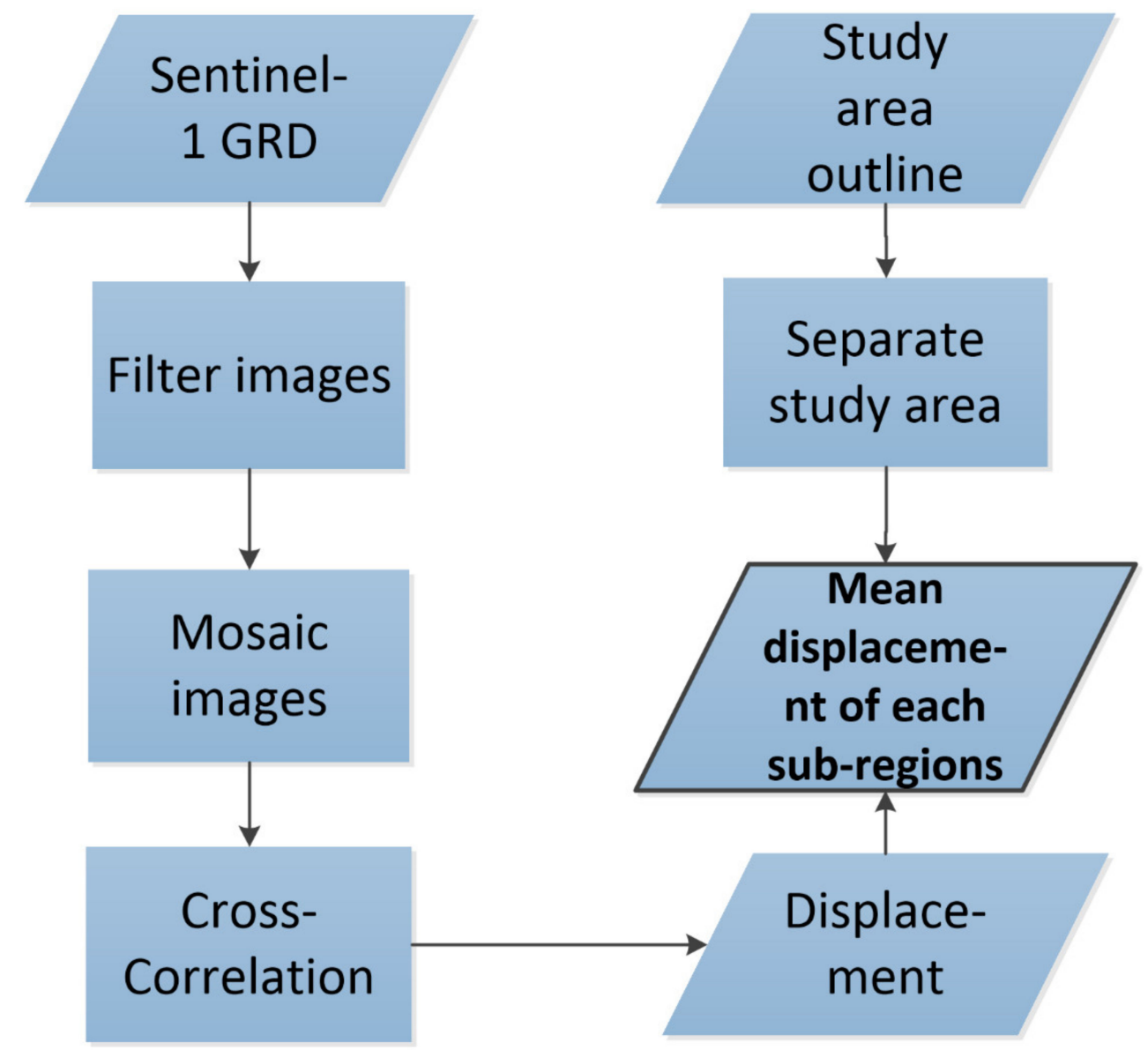

Figure 2. Flowchart of the processing methodology performed with the use of Google Earth Engine.

Table 3. Averaged surface velocities $\left(\mathrm{m} \mathrm{a}^{-1}\right)$ and standard deviation $( \pm 1 \sigma)$ of each image strip and time interval. The strip numbers of the two images in an image pair are given, and the two numbers in this item represent "relativeOrbitNumber" and "sliceNumber" of Sentinel-1 GRD data, respectively.

\begin{tabular}{ccccc}
\hline Image Strip (First) & Image Strip (Second) & Interval (days) & Date $^{\mathbf{1}}$ & ${\text { Accuracy }\left(\mathbf{m} \mathbf{a}^{-\mathbf{1}} \pm \mathbf{1} \boldsymbol{\sigma}\right)}$ \\
\hline 1076 & 1076 & 24 & $2015 / 02 / 10-03 / 06$ & $2.09 \pm 13.27$ \\
1076 & 1076 & 18 & $2016 / 09 / 20-10 / 08$ & $2.45 \pm 9.02$ \\
1076 & 1076 & 12 & $2017 / 03 / 19-03 / 31$ & $3.01 \pm 11.75$ \\
$1071 / 2$ & $1071 / 2$ & 24 & $2015 / 04 / 11-05 / 05$ & $1.87 \pm 5.36$ \\
1076 & $1071 / 2^{2}$ & 12 & $2015 / 05 / 17-05 / 29$ & $1.14 \pm 4.27$ \\
1076 & 347 & 45 & $2015 / 8 / 21-2015 / 10 / 15^{3}$ & $2.43 \pm 6.27$ \\
\hline
\end{tabular}

\footnotetext{
${ }^{1}$ We chose one image pair to calculate the accuracy of specific image strip and interval. 2 " 107 1/2" represents the mosaic of two images with "relativeOrbitNumber" is " 107 ", and the "sliceNumber" is " 1 " and" 2" respectively. ${ }^{3}$ This image pair is used for accuracy assessment with field measurement and only used once in this study.
} 


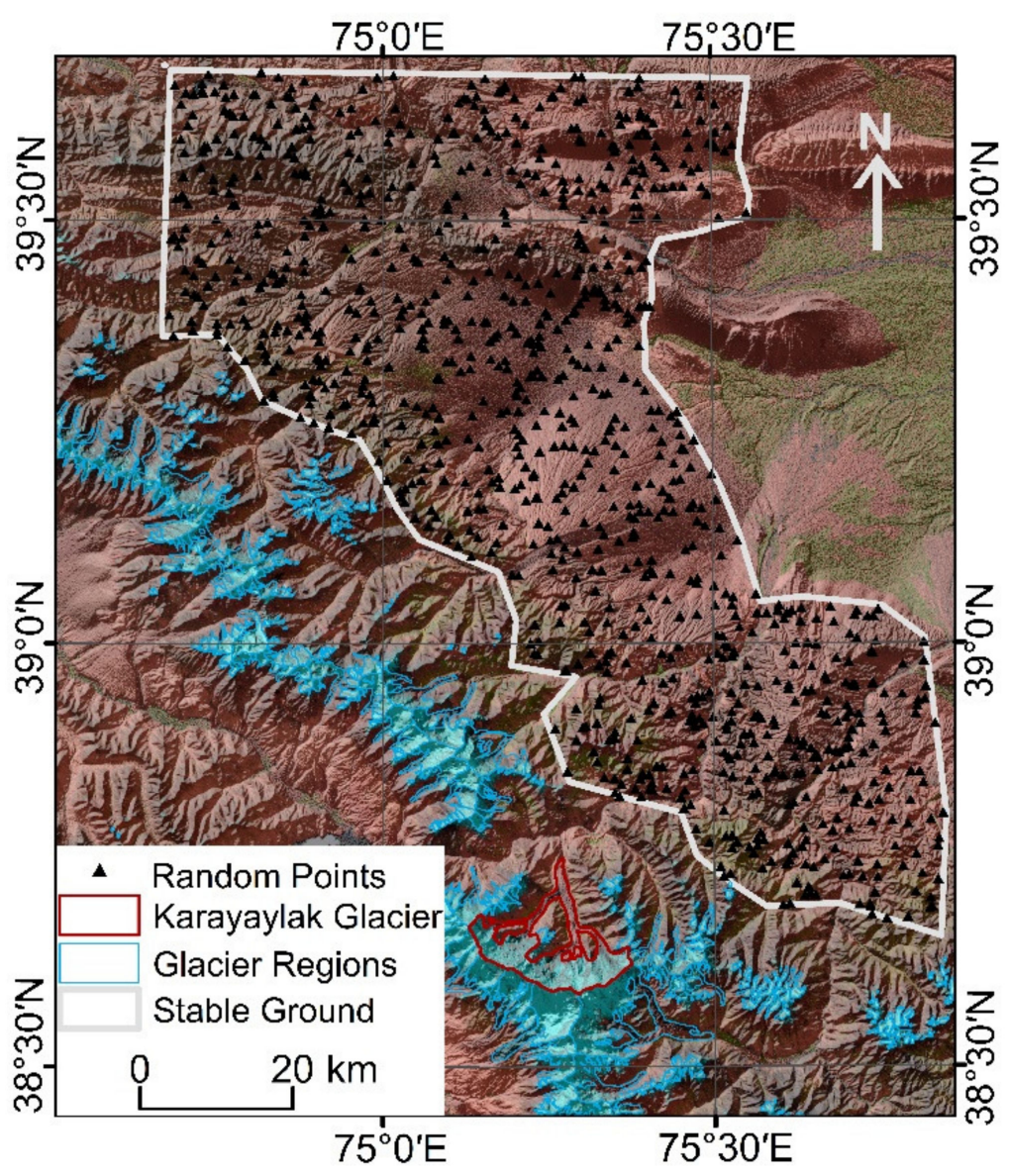

Figure 3. Overview of the stable ground around the Karayaylak glacier and 1000 random samples. The background image is the mosaic of two Landsat 8 scenes acquired on 11 July 2015 and 9 September 2017 and the NASA SRTM DEM.

\section{Results}

5.1. Surface Velocity

5.1.1. The Change of Surface Velocity in General

The continuous velocity time series from 13 October 2014 to 17 October 2020 is shown in Figure 4 (with 5-point moving averages). Figure 4 shows the mean velocity in the 10 sub-regions. The highest mean velocity during the study period was $2395.13 \mathrm{~m} \mathrm{a}^{-1}$ (11 April to 17 May 2015). The velocities before this phase and from 17 May to 28 July 2015 showed rapid acceleration and deceleration, respectively. The average speed increase across all 10 bins was $866.14 \mathrm{~m} \mathrm{a}^{-1}$, and the average subsequent decrease was $2221.91 \mathrm{~m} \mathrm{a}^{-1}$. During 11 April to 17 May, the region from the lower west branch to the terminus (bin 6) showed the fastest movement, reaching a maximum of $4264.79 \mathrm{~m} \mathrm{a}^{-1}$ in the surge phase. After the active phase, i.e., from 28 July 2015 to 19 December 2016, the entire west branch and terminus of Karayaylak Glacier stabilized. Surface velocities showed typical annual periodicity from 2017 to 2020, with velocities remaining slightly higher than those during the post-surge period of 28 July 2015 to 19 December 2016. The above analysis indicated that (1) this glacier surge occurred from 11 April to 17 May 2015; (2) the west branch and terminus of Karayaylak glacier were already in an active state after 13 October 2014; (3) the glacier appeared to be returning to a quiescent phase after July 2015; and (4) the glacier showed relatively active movement after a quiescent period in 2016. Shangguan and others (2016) [19] suggested that the complete surge phase of Karayaylak was from 13 April 2015 to $\sim 16$ June 2015, while we considered the period with most intense movement as a more specific surge phase. However, this definition does not affect the consistency between the 
two studies. By cross-correlation calculations of Landsat-8 images from 3 October 2014 and 13 April 2015, Shangguan and others assessed the preceding active state of glacier. The consecutive velocities from 13 October 2014 to 13 April 2015, as calculated in this study, showed the steady acceleration before the surge. This is consistent with Shangguan et al., and here we extend the study period to 2020 to reveal the relatively active state of the glacier.

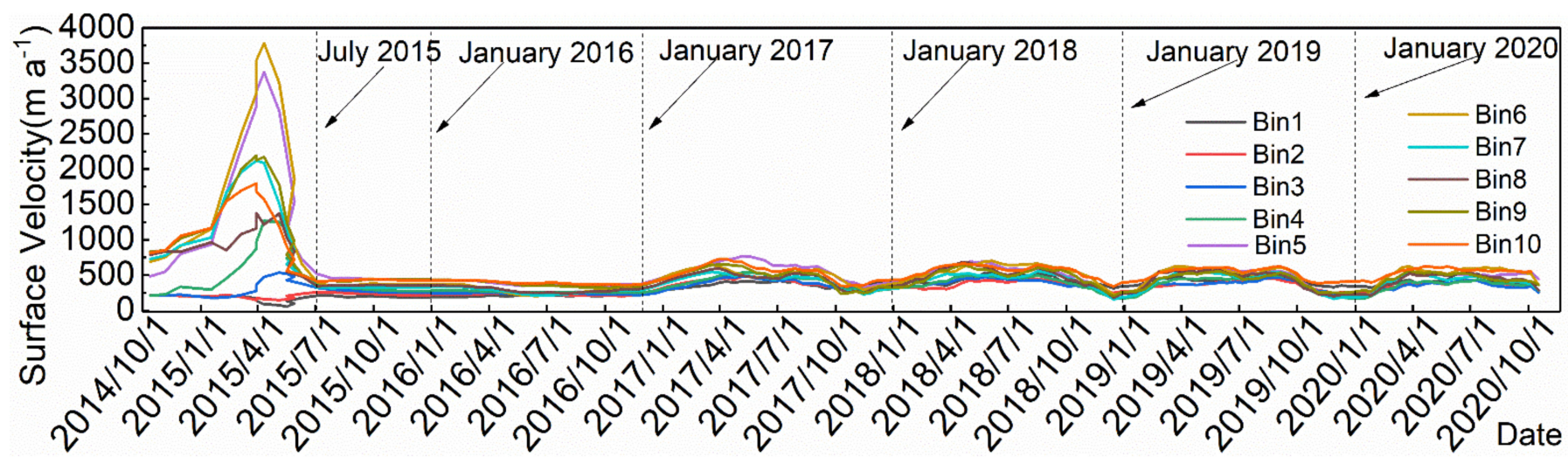

Figure 4. Surface velocity (mean values of the bins) at an interval of 12/18/24 from 13 October 2014 to 17 October 2020. Bin 1 to Bin 10 represents 10 sub-regions separated at $1 \mathrm{~km}$ equidistance along the centreline of terminus and west branch of Karayaylak glacier.

5.1.2. The Spatio-Temporal Change of Surface Velocity before, during and after the Surge

The greatest spatio-temporal variability in glacier velocity was observed from 13 October 2014 to 7 December 2015 (Figure 5). This period was divided into three parts. Velocities remained high from 30 March to 4 July 2015 (Figure 5a); speeds before the peak (the solid line in Figure $5 b$ ) and after the peak (the dotted line in Figure $5 b$ ) also show distinct characteristics. (1) Before the peak (13 October 2014 to 30 March 2015), and as shown in Figure $5 \mathrm{~b}$, the velocities accelerated continuously and showed a total mean increase of $874.03 \mathrm{~m} \mathrm{a}^{-1}$. However, the velocities of the glacier terminus did not increase. In contrast, the lower section and terminus of the west branch, $4-6 \mathrm{~km}$ up-glacier from the main glacier terminus, exhibited significant acceleration. Simultaneously, as shown in Figures $5 \mathrm{~b}$ and $6 \mathrm{a}-6 \mathrm{~d}$, the west branch glacier terminus speeds were much higher than those of the main glacier terminus in the surge build-up phase, which indicates that this surge event originated in the west branch. (2) A continuous time series of peak velocities is displayed in Figure 5a. The maximum velocities in the study period occurred from 11 April to 10 June 2015, representing an average increase in speed of $2889.66 \mathrm{~m} \mathrm{a}^{-1}$. As shown in Figures $5 \mathrm{a}$ and $6 \mathrm{f}-6 \mathrm{i}$, we found the greatest movement at the terminus of the glacier's west branch. The velocities at 3-4 $\mathrm{km}$ up-glacier from the terminus increased further, owing to ice advance from the west branch during the surge. It is noteworthy that the west branch terminus (bin 6) reached the highest velocity during the entire study period, of $4335.40 \mathrm{~m} \mathrm{a}^{-1}$, while the middle and upper parts of the west branch (bins 6-10) were still accelerating. This is in contrast to the other four periods of deceleration at bins 6-10. (3) The velocities after the surge are shown by the dotted line in Figure 5b. Velocity of the west branch showed a considerable decline, coincident with the decline in main glacier terminus velocity. The entire west branch of the Karayaylak glacier gradually stabilized, and its average velocities ranged from 216.13 to $468.46 \mathrm{~m} \mathrm{a}^{-1}$. 

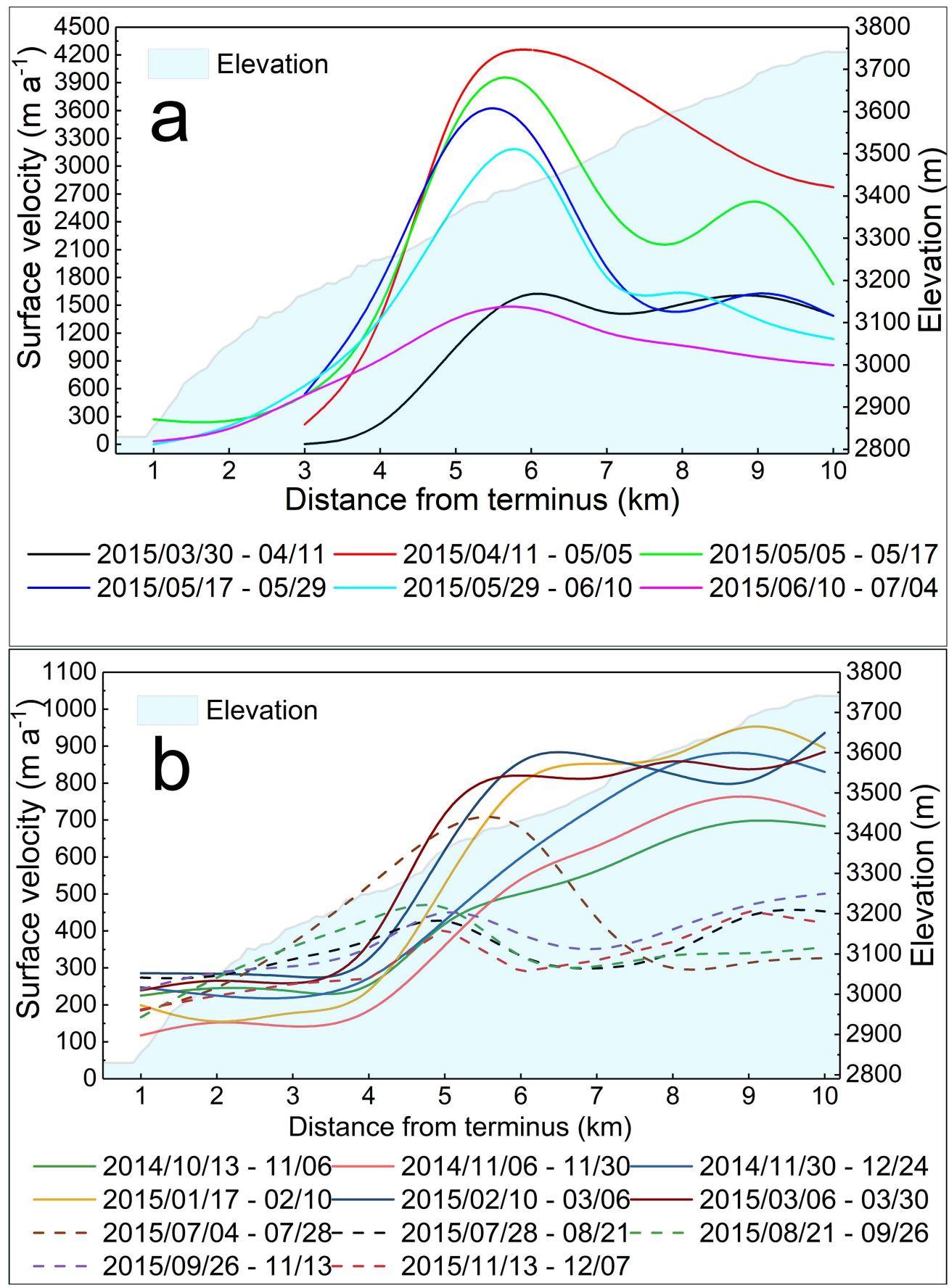

Figure 5. The most excessive surface velocity from 13 October 2014 to 7 December 2015. Panel (a) shows the velocities from 30 March 2015 to 4 July 2015. The solid line in panel (b) represents the velocity before 30 March and the dotted line shows the velocity after 30 March.

\subsubsection{The Change of Surface Velocity from 2016 to 2020}

Figures $6 \mathrm{k}-\mathrm{o}$ and 7 show annual glacier velocity and its spatial variations each July from 2016 to 2020, showing in particular the post-surge quiescence and the periodic variations. The average velocities of the 10 sub-regions during each of those five individual years were $291.56 \mathrm{~m} \mathrm{a}^{-1}, 454.22 \mathrm{~m} \mathrm{a}^{-1}, 461.51 \mathrm{~m} \mathrm{a}^{-1}, 422.53 \mathrm{~m} \mathrm{a}^{-1}$ and $423.64 \mathrm{~m} \mathrm{a}^{-1}$, respectively (the average velocity of the 10 sub-regions of each image pair was used to calculate the annual average velocity here and below). The velocities were slower and less variable from the end of the surge to the end of 2016. Interestingly, an increase in velocity, and the onset periodic variability, was observed in 2017 and lasted until the end 
of the study period. As shown in Figure 7b-e, from 2017 to 2020, the velocities increased steadily from January to April each year: the differences between the annual peak and the velocity in early January were $292.13 \mathrm{~m} \mathrm{a}^{-1}, 243.64 \mathrm{~m} \mathrm{a}^{-1}, 342.64 \mathrm{~m} \mathrm{a}^{-1}$ and $198.92 \mathrm{~m} \mathrm{a}^{-1}$, respectively. Ice velocity remained high during April to September, with annual peaks during the periods 18 to 30 May, 19 April to 30 May, 19 April to 10 May, 24 August to 5 September and 2 May to 14 May (at $590.24 \mathrm{~m} \mathrm{a}^{-1}, 609.85 \mathrm{~m} \mathrm{a}^{-1}, 591.38 \mathrm{~m} \mathrm{a}^{-1}$ and $\left.580.48 \mathrm{~m} \mathrm{a}^{-1}\right)$, respectively. From September to December, the velocities decreased by $236.11 \mathrm{~m} \mathrm{a}^{-1}, 361.22 \mathrm{~m} \mathrm{a}^{-1}, 438.26 \mathrm{~m} \mathrm{a}^{-1}$ and $248.19 \mathrm{~m} \mathrm{a}^{-1}$ in the years 2017 to 2020, respectively (here reported as the difference between peak velocity and late-December velocity). Spatial velocity patterns showed no individual fast-moving parts of the glacier during this period (Figure $6 \mathrm{k}-\mathrm{O}$ ).

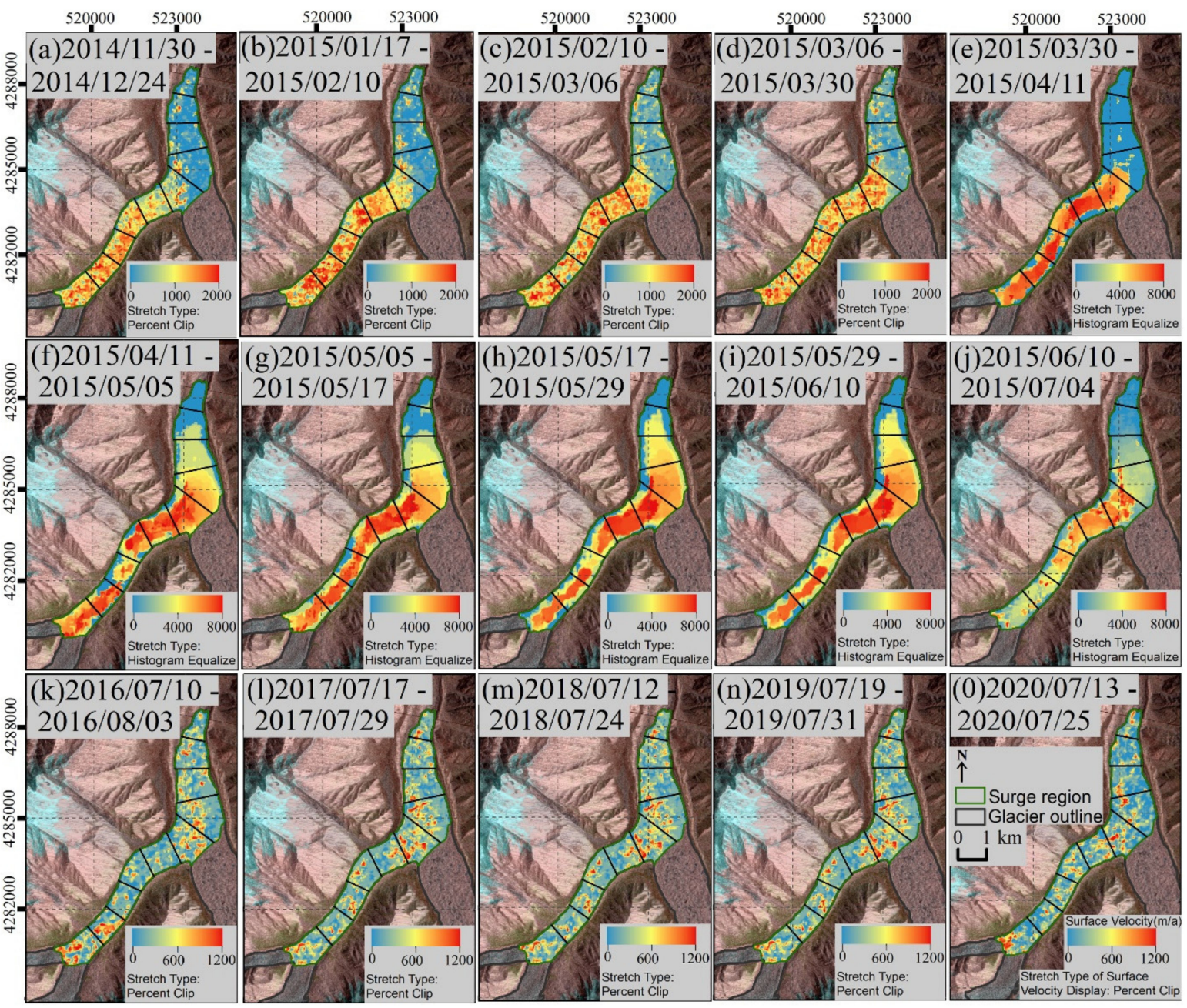

Figure 6. Surface velocities retrieval results of most phase from 13 October 2014 to 4 July 2015 (panel (a-j)) and each July from 2016 to 2020 (panel (k-o)). Due to the large span of velocity, especially in the surge phase, the values are displayed in different stretch types, including histogram equalize and percent clip. The legend and north arrow are shown in the panel (o). The background image is Landsat 8 scenes acquired on 11 July 2015. All coordinates are in UTM WGS84 Zone 43.

\subsection{Glacier Surface Changes in Surge Phase}

We selected four high-quality Landsat 8 images to investigate the morphological evolution of the glacier surface and glacier extent in the surge phase (Figure 8). We did not detect the glacier tongue's advance. On the contrary, the west tributary terminus presented a continuous advance from 13 April to 11 July 2015, as indicated by the curve representing the terminus position in Figure 8. However, this position does not reflect the 
period of highest velocity, when the ice flow direction shifted towards that of the main glacier as the west branch became obstructed by the east branch. The west branch also turns northeast at $6 \mathrm{~km}$ from the terminus (altitude around $3450 \mathrm{~m}$ a.s.l.), two arrows in Figure 8 indicate the two main ice streams at this turn during the advance phase of the surge. Meanwhile, as shown in Figure $6 \mathrm{e}-\mathrm{j}$, this position also presented the highest velocity during the surge time.

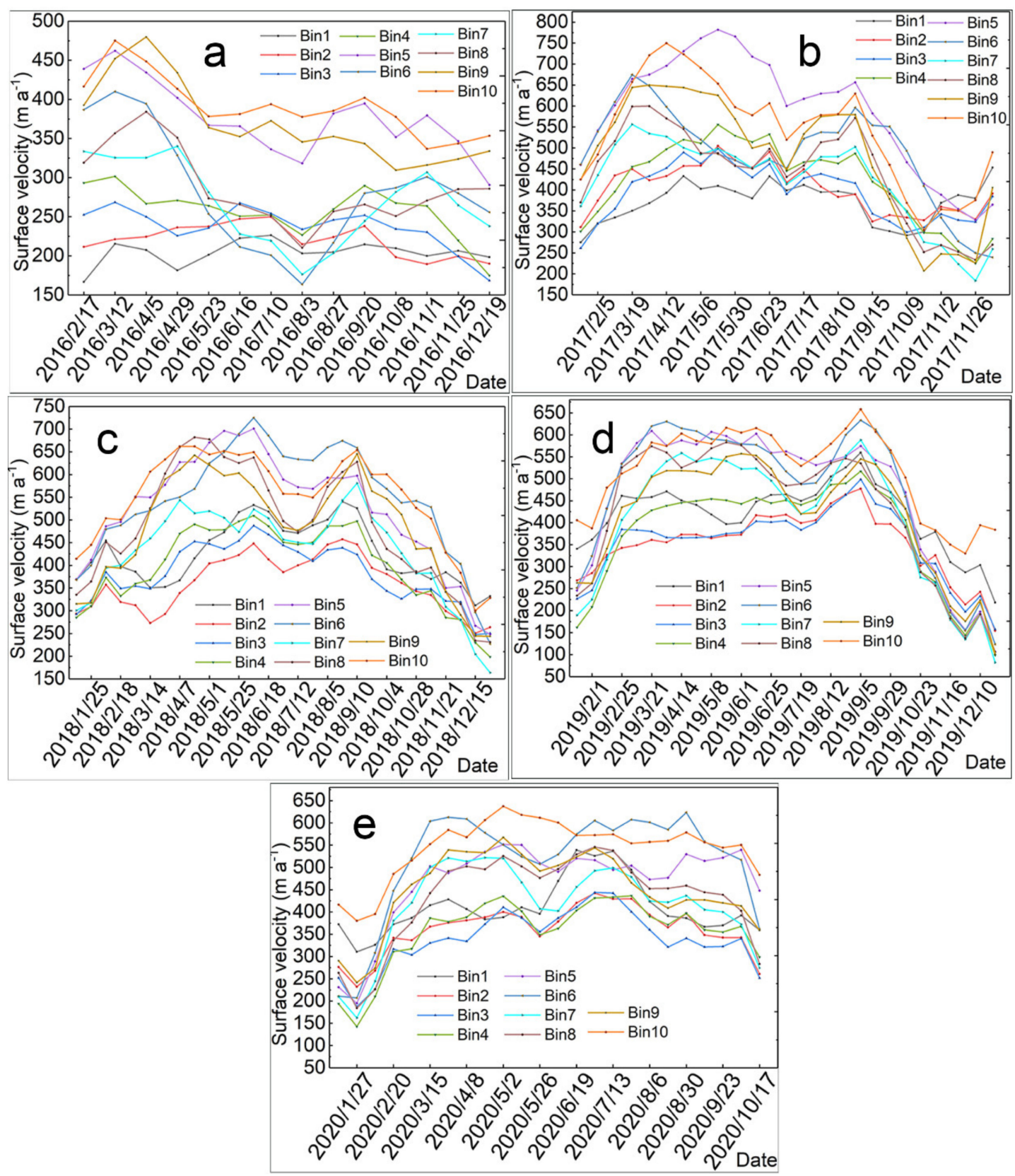

Figure 7. The velocity retrieval results from 17 February 2016 to 17 October 2020 displayed by year. Panel (a-e) respectively represent the surface velocity from 2016 to 2020.

\subsection{The Uncertainty Analysis Based on the Field Data}

We selected two Sentinel-1 GRD images of the study region, with dates of 21 August 2015 and 15 October 2015, corresponding to the "relativeOrbitNumber_start "and "sliceNumber "of "107 and 6 "and " 34 and 7", respectively, to analyze the correlation between the ground-based measurements and the remote-sensing results in the same period and 
position. Velocities in this image pair were computed with a window size and maximum displacement of 7 and 35 pixels, thus providing the average daily velocities at 3 ablation stakes and 56 feature points (Figure 9a). As shown in Figure 9b, the NCC results represent the pixel offset distances in the horizontal and vertical directions, but the field feature points were not located in the fast-moving part, which caused low calculated velocities in the field investigation period. Thus, although many similar velocities were extracted by remote sensing, these were not matched by field observations. Nevertheless, this does not affect the matching between remote-sensing retrievals and ground-based measurements. The average absolute velocity difference between remote-sensing and field data was $0.10 \mathrm{~m} / \mathrm{d}$. The correlation is indicated in Figure 9a, demonstrating that the method used here can be used for glacier velocity monitoring with high accuracy.

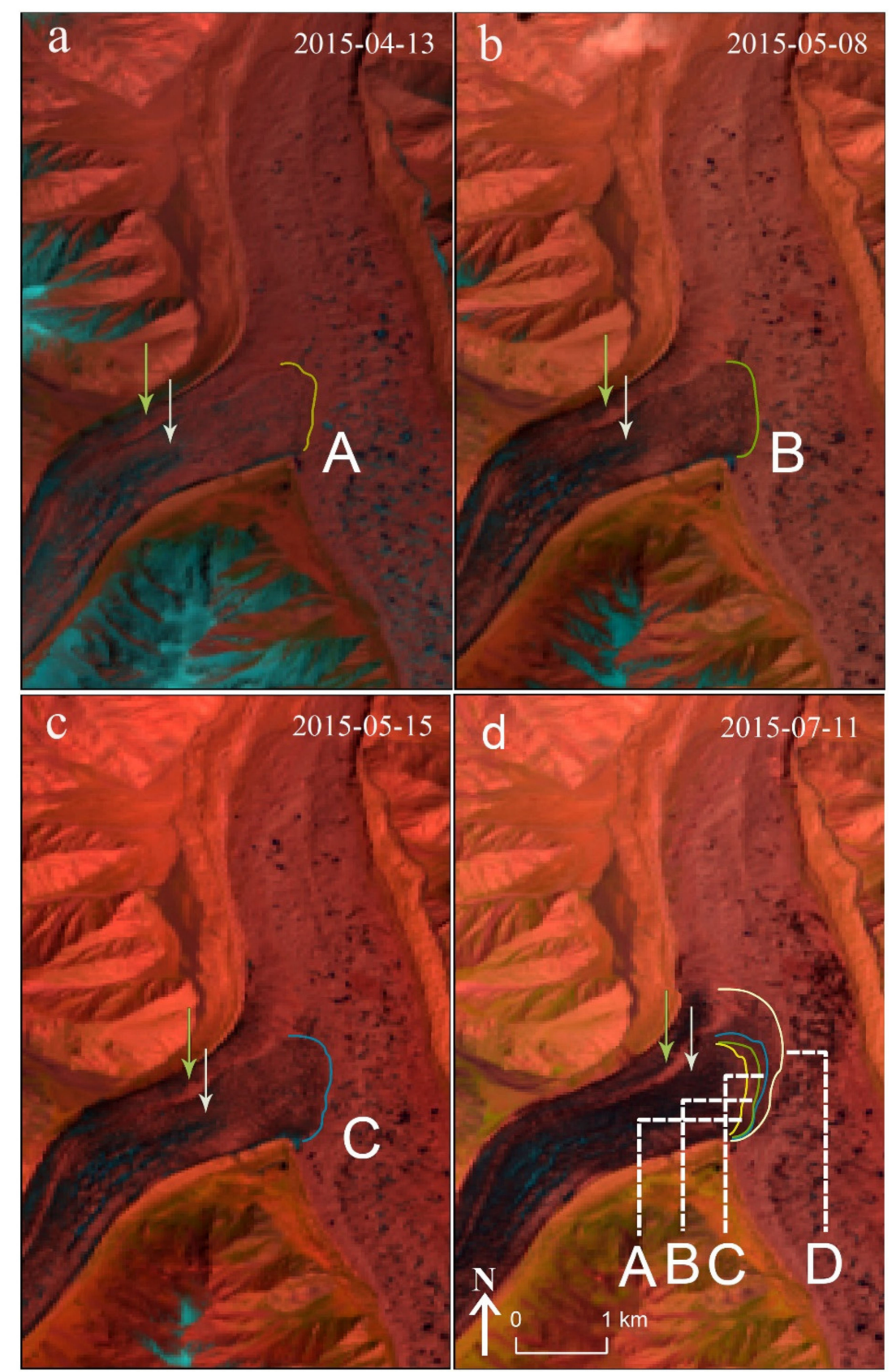

Figure 8. Panel (a-d) show the confluence of the west branch of Karayaylak glacier and the main glacier on 13 April, 8 May, 15 May and 11 July 2015. The background image is Landsat 8. A, B, C, D in the figure note the west tributary terminus location in multiple periods. 

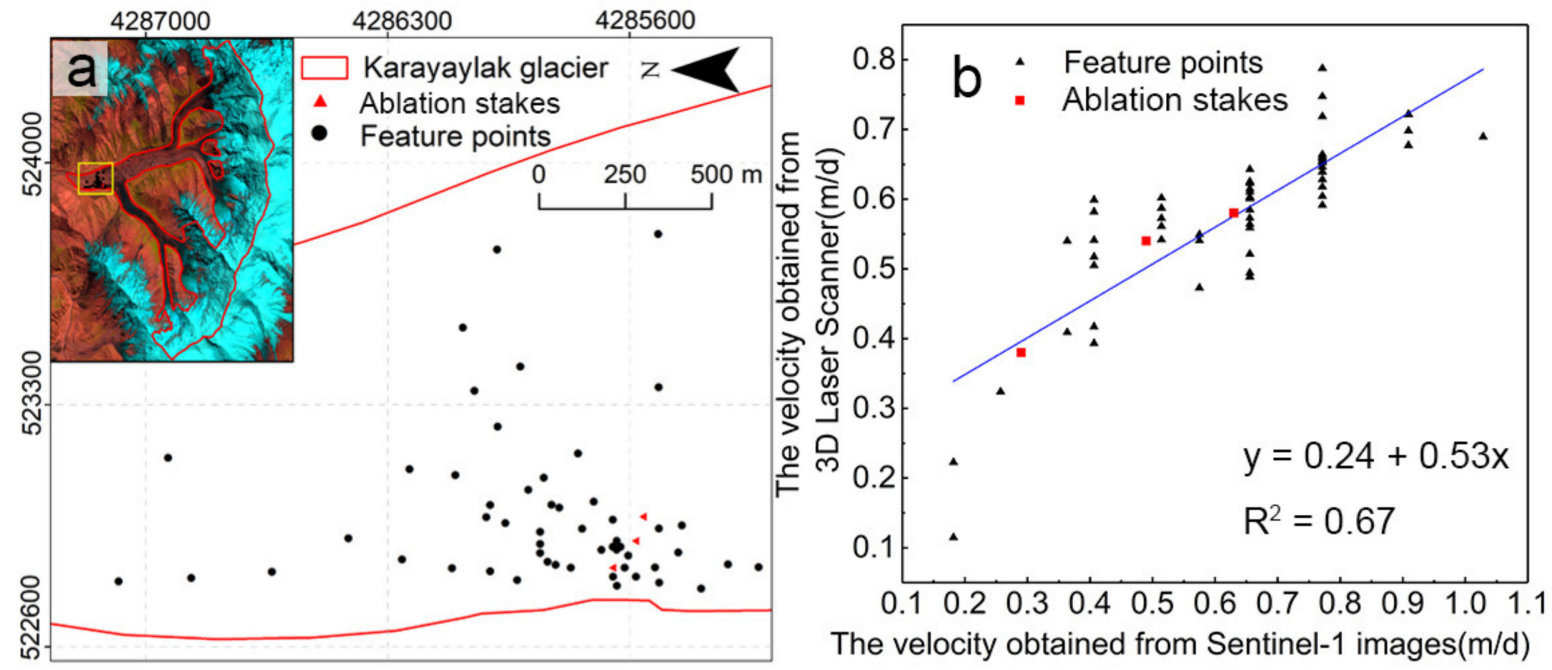

Figure 9. (a) shows the location of the feature points and lining poles. (b) indicates the correlation of velocity based on Sentinel-1 images and 3D Laser Scanner, and velocity is represented by 56 feature points and three stacks.

\section{Discussion}

\subsection{Accuracy of Glacier Surface Velocity}

The errors in this study include the Google Earth Engine processing error and crosscorrelation error. The correlation error was assessed in Section 4.2. However, GEE processing errors are poorly defined. To maximize confidence in our results, the ground-based measurements were compared with the remote sensing retrievals. The 3D terrestrial laser scanning (TLS) uncertainties related to the instability of the TLS [80] and registration error of scan positions [81]. The instability of laser scanning is derived from small displacement of scan positions and the vibration of 3D laser scanner. Thus, we established each scan position on stable rock surfaces using reinforced concrete. Our experience was conducted with the windless weather conditions to avoid the 3D laser scanner's vibration. The standard deviation of errors $\left(\partial_{\mathrm{MSA}}\right)$ from the set of residuals obtained from registering the point cloud can be considered as an indication of registration quality [82]. The value of $\partial_{\mathrm{MSA}}$ in this study is $0.07 \mathrm{~m}$. The good correlation between these two methods certified the high accuracy of velocity extraction based on the GEE platform, which provides a powerful computing tool in glaciology.

Sund et al. [83] reported that the surge occurred in three stages. Stage 1 was characterized by an initial surface lowering and acceleration in a section of the accumulation area. Stage 2 is defined as a larger mass displacement, with continuous surface lowering in the accumulation basin and down-glacier mass transport towards the ablation area. In stage 3, the pronounced acceleration extended throughout the glacier, and the terminus advanced. Not all glacier surges show these 3 typical stages. In an internal surge, the glacier surge terminates within another tributary of the glacier or its main trunk. This type of glacier surge is mainly found in compound valley glaciers [19]. In this study, rapid advance of the glacier's main terminus was not detected during the study period. However, the west branch of Karayaylak glacier accelerated strongly and its ice tongue advanced. Therefore, the surge was restricted within the west branch of the glacier, in contrast to typical stage 3 characteristics. Stages 1 and 2 were identified by glacier thickness and velocity changes, when the glacier was in in the active phase. This paper presents velocities during Stages 1 and 2 (October 2014 to July 2015). From July 2015 to the end of 2016, velocities decreased to their lowest values of the study period. After 2017, slight acceleration and an annual peak during April to September each year indicated that Karayaylak Glacier had returned to its active state again after the short quiescence. This activity should be closely monitored. 


\subsection{Surge Mechanism Analysis}

To analyze the surge mechanism of Karayaylak Glacier, we first correlated air temperature at the automatic meteorological station with that at surrounding meteorological stations from 15 August to 6 October 2015. This indicated that the Tashkurgan station had the best match with the automatic station $(R=0.8444)$. Therefore, we obtained the 1957 to 2015 air temperature at Tashkurgan station (Figure 10) from the China Meteorological Data Network [84] and used this to analyze the glacier surge mechanism.

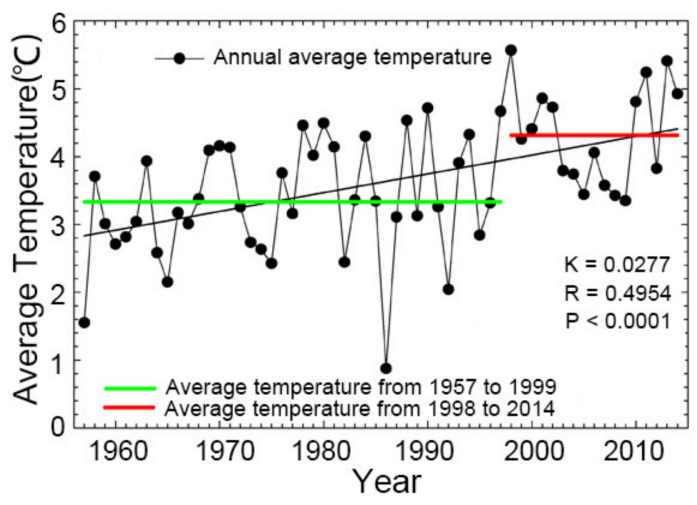

Figure 10. The annual average temperature of the Tashkurgan meteorological station from 1957 to 2015.

The glacier surge mechanism includes thermal and hydrological controls. In the thermal control mechanism, rising air temperatures lead to increasing ice temperature at the glacier bed. The resulting increase in subglacial meltwater triggers the surge [14,85]. This thermal trigger only operates at the interface between cold and warm subglacial conditions, normally in the upper regions of tributaries in dendritic glaciers. Therefore, this process mostly leads to internal surges and is directly related to climate warming [85]. In the hydrological control mechanism, excess meltwater formed by warming temperatures or other reasons cannot drain out quickly due to changes or obstructions in the subglacial drainage system [86,87].

The above thermal control is consistent with the Karayaylak Glacier surge and many glaciers in the Karakoram [25]. Thus, we considered this as the primary mechanism leading to the surge of Karayaylak Glacier. However, the thermal control cannot fully explain the surge initiation. As shown in Figure 10, the rapid air temperature increase at Tashkurgan after 1998 caused basal ice temperature to reach the melting point, suggesting that the surge was enabled by conditions at that time. However, the thermal control mechanism theory does not consider what factors trigger the surge. Besides, surges based on the thermal control mechanism may occur at any time of the year, while surges based on the hydrological control mechanism generally occur in winter [86]. The timing suggests this surge was more likely to have been triggered by the hydrological mechanism. Here, our detailed analysis suggest that the thermal control mechanism established optimal surge conditions, but the hydrological control mechanism triggered the surge; therefore, both processes were involved, as described in the following section.

The "upper cold, bottom warm" polythermal glaciers [87] distributed in the Karakoram, Pamir Plateau and Tianshan include the intensively-studied Batura glacier [88], and Qingbingtan No. 72 glacier, Tuomuer Peak [89] which is less than $600 \mathrm{~km}$ straight-line distance from Karayaylak Glacier. Although this study lacks englacial ice temperature data, on the basis of the very wide elevation difference (7649 to $2780 \mathrm{~m}$ a.s.l.) we speculated that Karayaylak Glacier belongs to the "upper cold bottom warm" type. Karayaylak Glacier exhibits distinct cold and warm ice areas, as indicated by the respective absence or presence of well-developed drainage tunnels. In the context of climate warming and rising temperatures, we infer that the cold-warm boundary has extended rapidly up-glacier, 
leading to increasing meltwater production. This excess meltwater will be evacuated quickly by the existing subglacial drainage system in the warm zone. However, as the warm zone expands to areas without such tunnels, the hydraulic pressure will rise sharply as meltwater accumulates. This dynamic state, coupled with meltwater lubrication, is most likely to result in the initial glacier sliding, which triggers a glacier surge through positive feedback [87].

Analysis of Tashkurgan air temperature from October 2014 to July 2015 indicated the anomalous warming from February to April in 2015 (Figure 11), when maximum daily air temperature in February 2015 reached $4.3^{\circ} \mathrm{C}$. Here we focus on 12 consecutive days of high-temperatures from March 21 to April 1 (Figure 11), when the average temperature $\left(7.1^{\circ} \mathrm{C}\right)$ was $7.2^{\circ} \mathrm{C}$ higher than the mean for this period. Using an air temperature lapse rate of $0.7{ }^{\circ} \mathrm{C}(100 \mathrm{~m})^{-1}$ [90], this daily mean temperature corresponds to $-0.8{ }^{\circ} \mathrm{C}$ at $4300 \mathrm{~m}$ altitude, with a daily mean maximum temperature of $5.3^{\circ} \mathrm{C}$. Twelve days at these temperatures will have caused intensive ice surface ablation and melt water production; due to poorly-developed supraglacial and englacial drainage, this meltwater will have entered the ice through cracks and the glacier margin. This was most likely the main trigger of the surge.

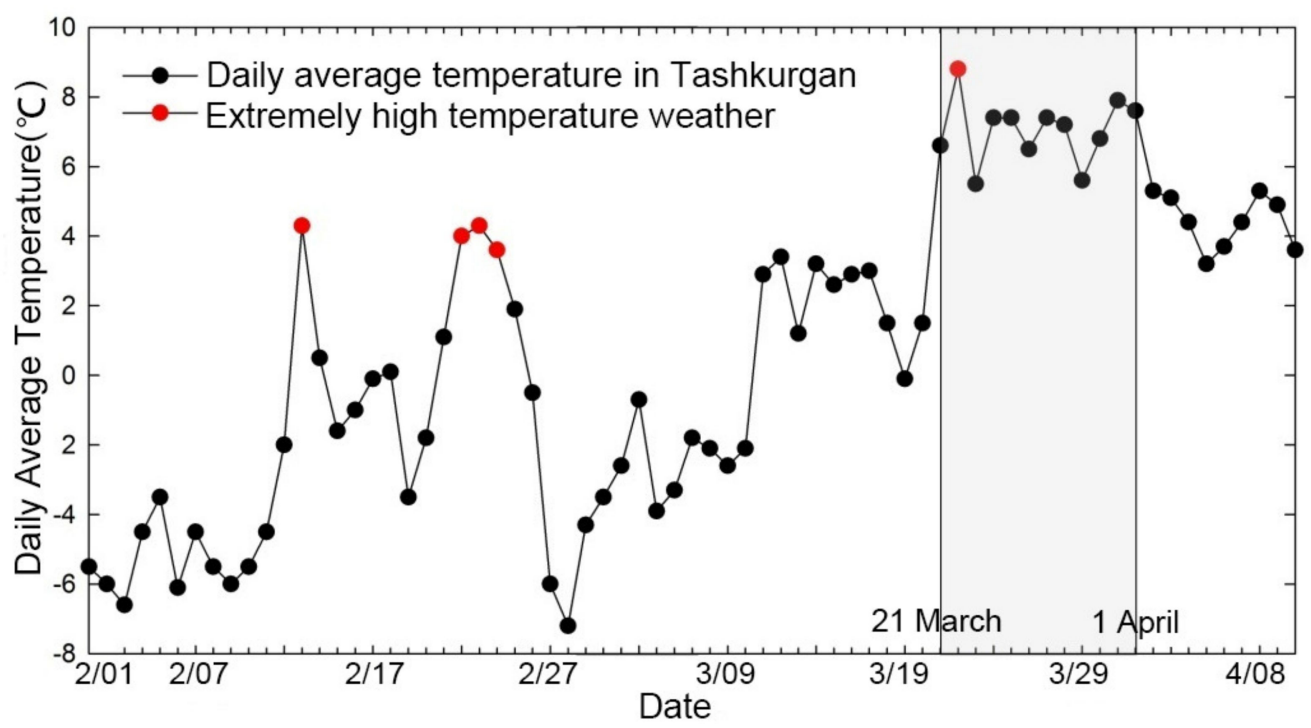

Figure 11. The daily average temperature in Tashkurgan from 2015/2/1 to 2015/4/08 and emphasized the high-temperature period from 21 March to 1 April.

The possibility that the surge was triggered below the boundary between cold and warm ice is discussed further as follows. Before the surge, meltwater from the warm ice area below the cold-warm transition can drain easily though the existing drainage system, and will not trigger a surge [91]. However, if drainage tunnels are blocked for some reason, hydraulic pressure will rapidly increase, and eventually trigger a surge [85]. In theory, four reasons can cause changes to drainage tunnels: (1) increased pressure in the accumulation zone increases shear stress in basal ice; (2) subglacial temperature changes modify the temperature distribution in the ice and bedrock; (3) increased meltwater erodes drainage tunnels and causes them to collapse; (4) the ice bed comprises soft sediments which support only a weak drainage system that is easily altered.

At first, we thought that the first factor (increased shear stress in basal ice) was the main trigger, because Karayaylak Glacier's mass balance increased by $0.37 \pm 0.25$ m w.e. $\mathrm{a}^{-1}$ from 1999 to 2013/2014 [74]. However, according to the meteorological data for Tashkurgan, we found the precipitation from January to April of recent years was lower than the long-term average, especially during 2014 and 2015. Our inference would then depend on inaccurate mass balance data due to a lack of snow depth datasets. Thus, the 
shear stress trigger is lacking in supporting data. While we note that the accumulation rate on the upper glacier remains uncertain due to a lack of precipitation observations from the upper glacier, the first factor can be eliminated, and the other three factors causing changing subglacial drainage remain plausible. Therefore, the possibility that the surge was triggered by the hydrological control mechanism below the cold-warm transition is very high. Besides the "hydraulic effect" of meltwater, the "lubrication effect" cannot be ignored in these processes [91].

Our comprehensive analysis has indicated that the Karayaylak Glacier surge was likely triggered in the upper part of the glacier, but quickly propagated to cause a surge in the entire glacier branch. Continuous climate warming very likely caused the increasing meltwater and created favorable conditions for the surge. After October 2014, the glacier terminus and west branch velocity nearly doubled, indicating the onset of basal sliding or subglacial sediment deformation, prior to the main trigger. Warm air temperatures from 21 March to 1 April provided this trigger. This clearly shows that the surge mechanism is not a single process: instead, it comprises coupled thermal and hydrological controls, which play different roles at different times and places. The two mechanisms interact to produce superimposed effects.

\section{Conclusions}

This study retrieved the surface velocities of the west branch and terminus of Karayaylak Glacier from 13 October 2014 to 17 October 2020, using Sentinel-1 GRD imagery and the GEE platform. The glacier dynamic and remote-sensing retrieval methods are focused on in this paper.

The west branch of Karayaylak Glacier had presented a substantial acceleration in October 2014. Velocities in May 2015 reached a maximum of $4335.40 \mathrm{~m} \mathrm{a}^{-1}$ at the west branch terminus which showed strenuous movement with its advance of about $3 \mathrm{~km}$. Thus, we concluded that this glacier tributary surge happened in May 2015 accordingly. Analysis of data at the automatic meteorological station and Tashkurgan meteorological station suggested that this surge resulted from coupled thermal and hydrological controls, with both playing different roles at a different times and altitudes. The velocities decreased sharply within two months after the surge and then remained slow for nearly a year. Since 2017, velocities have increased slightly and have shown the annual periodic variability, which revealed the current relative dynamic state of Karayaylak Glacier and should be closely monitored.

The accuracy assessment of field measurement and velocity retrieval was presented in this paper. Moreover, the high correlation between the field data and the remote sensingderived velocities supported this work's reliability. This demonstrated the high-precision monitoring method of the glacier surge based on the Sentinel-1 imagery and NCC, indicated in particular the great potential of the GEE platform to perform cloud-based computing in glaciology.

Author Contributions: Conceptualization: Y.P., Z.L. and C.X.; Methodology: Y.P.; Data curation: Y.P.; Ground-based measurements: Z.L., C.X. and H.Z.; Software: Y.P.; Validation: Y.P., Z.L. and C.X.; Formal analysis: Y.P., Z.L. and C.X.; Investigation: Y.P., Z.L. and C.X.; Writing-original draft: Y.P.; Writing—review and editing: Z.L., C.X., H.Z. and W.H.; Visualization: Y.P.; Supervision: Z.L.; Funding acquisition, project administration and resources: Z.L. All authors have read and agreed to the published version of the manuscript.

Funding: This work is supported by the State Key Laboratory of Cryospheric Science founding (SKLCS-ZZ-2020), the Second Tibetan Plateau Scientific Expedition and Research (2019QZKK0201), the Strategic Priority Research Program of Chinese Academy of Sciences (Class A) (XDA20020102), the Innovative Research Groups of the National Natural Science Foundation (No. 41721091), the Strategic Priority Research Program of Chinese Academy of Sciences (Class A) (XDA20060201), National Cryosphere Desert Data Center( No.20D03), and National Natural Science Foundation of China (No.42001067, No. 41771077). 
Data Availability Statement: Surface velocities retrieval results are available upon request by email to the author(2019212427@nwnu.edu.cn).

Acknowledgments: We are grateful for using the Google Earth Engine platform and Sentinel-1 imagery in this study.

Conflicts of Interest: The authors declare no conflict of interest.

\section{References}

1. Yao, T.; Thompson, L.; Yang, W.; Yu, W.; Gao, Y.; Guo, X.; Yang, X.; Duan, K.; Zhao, H.; Xu, B. Different glacier status with atmospheric circulations in Tibetan Plateau and surroundings. Nat. Clim. Chang. 2012, 2, 663-667. [CrossRef]

2. Yao, T.; Thompson, L.G.; Mosbrugger, V.; Zhang, F.; Ma, Y.; Luo, T.; Xu, B.; Yang, X.; Joswiak, D.R.; Wang, W. Third pole environment (TPE). Environ. Dev. 2012, 3, 52-64. [CrossRef]

3. RGI Consortium. Randolph Glacier Inventory-A Dataset of Global Glacier Outlines: Version 6.0: Technical Report, Global Land Ice Measurements from Space, Colorado, USA. Digital Media. 2017. Available online: https://doi.org/10.7265/N5-RGI-60 (accessed on 16 February 2021).

4. Mölg, N.; Bolch, T.; Rastner, P.; Strozzi, T.; Paul, F. A consistent glacier inventory for the Karakoram and Pamir derived from Landsat data: Distribution of debris cover and mapping challenges. Earth Syst. Sci. Data Discuss. 2018, 10, 1807-1827. [CrossRef]

5. Scherler, D.; Bookhagen, B.; Strecker, M.R. Spatially variable response of Himalayan glaciers to climate change affected by debris cover. Nat. Geosci. 2011, 4, 156-159. [CrossRef]

6. Brun, F.; Berthier, E.; Wagnon, P.; Kääb, A.; Treichler, D. A spatially resolved estimate of High Mountain Asia glacier mass balances from 2000 to 2016. Nat. Geosci. 2017, 10, 668-673. [CrossRef]

7. Azam, M.F.; Wagnon, P.; Berthier, E.; Vincent, C.; Fujita, K.; Kargel, J.S. Review of the status and mass changes of HimalayanKarakoram glaciers. J. Glaciol. 2018, 64, 61-74. [CrossRef]

8. Gardelle, J.; Berthier, E.; Arnaud, Y. Slight mass gain of Karakoram glaciers in the early twenty-first century. Nat. Geosci. 2012, 5, 322-325. [CrossRef]

9. Maurer, J.M.; Schaefer, J.; Rupper, S.; Corley, A. Acceleration of ice loss across the Himalayas over the past 40 years. Sci. Adv. 2019, 5, eaav7266. [CrossRef]

10. Jacob, T.; Wahr, J.; Pfeffer, W.T.; Swenson, S. Recent contributions of glaciers and ice caps to sea level rise. Nature 2012, 482, 514-518. [CrossRef] [PubMed]

11. Sevestre, H.; Benn, D.I. Climatic and geometric controls on the global distribution of surge-type glaciers: Implications for a unifying model of surging. J. Glaciol. 2015, 61, 646-662. [CrossRef]

12. Copland, L.; Sylvestre, T.; Bishop, M.P.; Shroder, J.F.; Seong, Y.B.; Owen, L.A.; Bush, A.; Kamp, U. Expanded and recently increased glacier surging in the Karakoram. Arct. Antarct. Alp. Res. 2011, 43, 503-516. [CrossRef]

13. Meier, M.F.; Post, A. What are glacier surges? Can. J. 1969, 6, 807-817. [CrossRef]

14. Sharp, M. Surging glaciers: Behaviour and mechanisms. Prog. Phys. Geogr. 1988, 12, 349-370. [CrossRef]

15. Raymond, C.F. How do glaciers surge? A review. J. Geophys. Res. Solid Earth 1987, 92, 9121-9134. [CrossRef]

16. Harrison, W.D.; Post, A.S. How much do we really know about glacier surging? Ann. Glaciol. 2003, 36, 1-6. [CrossRef]

17. Goerlich, F.; Bolch, T.; Paul, F. More dynamic than expected: An updated survey of surging glaciers in the Pamir. Earth Syst. Sci. Data 2020, 12, 3161-3176. [CrossRef]

18. Kotlyakov, V.; Osipova, G.; Tsvetkov, D. Monitoring surging glaciers of the Pamirs, central Asia, from space. Ann. Glaciol. 2008, 48, 125-134. [CrossRef]

19. Shangguan, D.; Liu, S.; Ding, Y.; Guo, W.; Xu, B.; Xu, J.; Jiang, Z. Characterizing the May 2015 Karayaylak Glacier surge in the eastern Pamir Plateau using remote sensing. J. Glaciol. 2016, 62, 944-953. [CrossRef]

20. Yao, X.; Iqbal, J.; Li, L.-j.; Zhou, Z.-k. Characteristics of mountain glacier surge hazard: Learning from a surge event in NE Pamir, China. J. Mt. Sci. 2019, 16, 1515-1533. [CrossRef]

21. Lv, M.; Lu, X.; Guo, H.; Liu, G.; Ding, Y.; Ruan, Z.; Ren, Y.; Yan, S. A rapid glacier surge on Mount Tobe Feng, western China, 2015. J. Glaciol. 2016, 62, 407-409. [CrossRef]

22. Feng, L.; Jiang, L.; Liu, L.; Sun, Y. Karayaylak glacier changes in the Kongur Mountain of eastern Pamir between 1973 and 2016 based on active and passive remote sensing technologies. Remote Sens. Land Resour. 2020, 32, 162-169. [CrossRef]

23. News, C. The Remove of Kongur Tagh Glacier in Xinjiang. Available online: http://www.chinanews.com/sh/2015/05-15/72797 00.shtml (accessed on 15 February 2021).

24. Bhambri, R.; Hewitt, K.; Kawishwar, P.; Pratap, B. Surge-type and surge-modified glaciers in the Karakoram. Sci. Rep. 2017, 7, 1-14. [CrossRef]

25. Paul, F.; Strozzi, T.; Schellenberger, T.; Kääb, A. The 2015 surge of Hispar Glacier in the Karakoram. Remote Sens. 2017, 9 , 888. [CrossRef]

26. Kääb, A.; Treichler, D.; Nuth, C.; Berthier, E. Brief Communication: Contending estimates of 2003-2008 glacier mass balance over the Pamir-Karakoram-Himalaya. Cryosphere 2015, 9, 557-564. [CrossRef]

27. Paul, F. Revealing glacier flow and surge dynamics from animated satellite image sequences: Examples from the Karakoram. Cryosphere 2015, 9, 2201-2214. [CrossRef] 
28. Holzer, N.; Vijay, S.; Yao, T.; Xu, B.; Buchroithner, M.; Bolch, T. Four decades of glacier variations at Muztagh Ata (eastern Pamir): A multi-sensor study including Hexagon KH-9 and Pléiades data. Cryosphere 2015, 9, 2071-2088. [CrossRef]

29. Yang, H.; Yan, S.; Liu, G.; Ruan, Z. Fluctuations and movements of the Kuksai Glacier, western China, derived from Landsat image sequences. J. Appl. Remote Sens. 2013, 8, 084599. [CrossRef]

30. Lv, M.; Guo, H.; Lu, X.; Liu, G.; Yan, S.; Ruan, Z.; Ding, Y.; Quincey, D.J. Characterizing the behaviour of surge-and non-surge-type glaciers in the Kingata Mountains, eastern Pamir, from 1999 to 2016. Cryosphere 2019, 13, 219-236. [CrossRef]

31. Singh, G.; Nela, B.R.; Bandyopadhyay, D.; Mohanty, S.; Kulkarni, A.V. Discovering anomalous dynamics and disintegrating behaviour in glaciers of Chandra-Bhaga sub-basins, part of Western Himalaya using DInSAR. Remote Sens. Environ. 2020, 246, 111885. [CrossRef]

32. Paul, F.; Barrand, N.E.; Baumann, S.; Berthier, E.; Bolch, T.; Casey, K.; Frey, H.; Joshi, S.; Konovalov, V.; Le Bris, R. On the accuracy of glacier outlines derived from remote-sensing data. Ann. Glaciol. 2013, 54, 171-182. [CrossRef]

33. Bolch, T.; Buchroithner, M.F.; Kunert, A.; Kamp, U. Automated delineation of debris-covered glaciers based on ASTER data. Proceedings of Geoinformation in Europe 27th EARSeL Symposium, Bolzano, Italy, 4-7 June 2007; pp. 4-6.

34. Robson, B.A.; Nuth, C.; Dahl, S.O.; Hölbling, D.; Strozzi, T.; Nielsen, P.R. Automated classification of debris-covered glaciers combining optical, SAR and topographic data in an object-based environment. Remote Sens. Environ. 2015, 170, 372-387. [CrossRef]

35. Racoviteanu, A.; Williams, M.W. Decision tree and texture analysis for mapping debris-covered glaciers in the Kangchenjunga area, Eastern Himalaya. Remote Sens. 2012, 4, 3078-3109. [CrossRef]

36. Kääb, A.; Berthier, E.; Nuth, C.; Gardelle, J.; Arnaud, Y. Contrasting patterns of early twenty-first-century glacier mass change in the Himalayas. Nature 2012, 488, 495-498. [CrossRef]

37. Braun, M.H.; Malz, P.; Sommer, C.; Farías-Barahona, D.; Sauter, T.; Casassa, G.; Soruco, A.; Skvarca, P.; Seehaus, T.C. Constraining glacier elevation and mass changes in South America. Nat. Clim. Chang. 2019, 9, 130-136. [CrossRef]

38. Hewitt, K. Tributary glacier surges: An exceptional concentration at Panmah Glacier, Karakoram Himalaya. J. Glaciol. 2007, 53, 181-188. [CrossRef]

39. Pope, A.; Rees, W.G. Impact of spatial, spectral, and radiometric properties of multispectral imagers on glacier surface classification. Remote Sens. Environ. 2014, 141, 1-13. [CrossRef]

40. Rosen, P.A.; Hensley, S.; Joughin, I.R.; Li, F.K.; Madsen, S.N.; Rodriguez, E.; Goldstein, R.M. Synthetic aperture radar interferometry. Proc. IEEE 2000, 88, 333-382. [CrossRef]

41. Tong, X.; Liu, S.; Li, R.; Xie, H.; Liu, S.; Qiao, G.; Feng, T.; Tian, Y.; Ye, Z. Multi-track extraction of two-dimensional surface velocity by the combined use of differential and multiple-aperture InSAR in the Amery Ice Shelf, East Antarctica. Remote Sens. Environ. 2018, 204, 122-137. [CrossRef]

42. Darvishi, M.; Schlögel, R.; Bruzzone, L.; Cuozzo, G. Integration of PSI, MAI, and Intensity-Based Sub-Pixel Offset Tracking Results for Landslide Monitoring with X-Band Corner Reflectors-Italian Alps (Corvara). Remote Sens. 2018, 10, 409. [CrossRef]

43. Paul, F.; Bolch, T.; Kääb, A.; Nagler, T.; Nuth, C.; Scharrer, K.; Shepherd, A.; Strozzi, T.; Ticconi, F.; Bhambri, R. The glaciers climate change initiative: Methods for creating glacier area, elevation change and velocity products. Remote Sens. Environ. 2015, 162, 408-426. [CrossRef]

44. Mahagaonkar, A.; Thakur, P.K.; Chang, L. Assessment of Sentinel-1 Products for Revealing Glacier Surface Movement in Indian Himalayas Using Differential SAR Interferometry. In Proceedings of the 2019 IEEE International Geoscience and Remote Sensing Symposium, Yokohama, Japan, 28 July-2 August 2019; pp. 2070-2073.

45. Nela, B.R.; Singh, G.; Kulkarni, A.V.; Malik, K. Optimum conditions for Differential SAR Interferometry technique to estimate Himalayan glacier velocity. ISPRS J. Photogramm. Remote Sens. 2018, 4, 137-140. [CrossRef]

46. Scambos, T.A.; Dutkiewicz, M.J.; Wilson, J.C.; Bindschadler, R.A. Application of image cross-correlation to the measurement of glacier velocity using satellite image data. Remote Sens. Environ. 1992, 42, 177-186. [CrossRef]

47. Altena, B.; Scambos, T.A.; Fahnestock, M.; Kääb, A. Extracting recent short-term glacier velocity evolution over southern Alaska and the Yukon from a large collection of Landsat data. Cryosphere 2019, 13, 795-814. [CrossRef]

48. Chen, Y.; Zhou, C.; Ai, S.; Liang, Q.; Zheng, L.; Liu, R.; Lei, H. Dynamics of Dalk Glacier in East Antarctica Derived from Multisource Satellite Observations Since 2000. Remote Sens. 2020, 12, 1809. [CrossRef]

49. Kääb, A. Combination of SRTM3 and repeat ASTER data for deriving alpine glacier flow velocities in the Bhutan Himalaya. Remote Sens. Environ. 2005, 94, 463-474. [CrossRef]

50. Heid, T.; Kääb, A. Evaluation of existing image matching methods for deriving glacier surface displacements globally from optical satellite imagery. Remote Sens. Environ. 2012, 118, 339-355. [CrossRef]

51. Scambos, T.; Fahnestock, M.; Moon, T.; Gardner, A.; Klinger, M. Global Land Ice Velocity Extraction from Landsat 8 (GoLIVE), Version 1. Available online: https:/ / doi.org/10.7265/N5ZP442B (accessed on 15 February 2021).

52. Goldstein, R.M.; Engelhardt, H.; Kamb, B.; Frolich, R.M. Satellite radar interferometry for monitoring ice sheet motion: Application to an Antarctic ice stream. Science 1993, 262, 1525-1530. [CrossRef]

53. Strozzi, T.; Luckman, A.; Murray, T.; Wegmuller, U.; Werner, C.L. Glacier motion estimation using SAR offset-tracking procedures. IEEE Trans. Geosci. Remote Sens. 2002, 40, 2384-2391. [CrossRef]

54. Rignot, E.; Mouginot, J.; Scheuchl, B. Ice flow of the Antarctic ice sheet. Science 2011, 333, 1427-1430. [CrossRef] [PubMed]

55. Satyabala, S. Spatiotemporal variations in surface velocity of the Gangotri glacier, Garhwal Himalaya, India: Study using synthetic aperture radar data. Remote Sens. Environ. 2016, 181, 151-161. [CrossRef] 
56. Mouginot, J.; Rignot, E.; Scheuchl, B.; Millan, R. Comprehensive annual ice sheet velocity mapping using Landsat-8, Sentinel-1, and RADARSAT-2 data. Remote Sens. 2017, 9, 364. [CrossRef]

57. Huang, L.; Li, Z. Comparison of SAR and optical data in deriving glacier velocity with feature tracking. Int. J. Remote Sens. 2011, 32, 2681-2698. [CrossRef]

58. Lemos, A.; Shepherd, A.; McMillan, M.; Hogg, A.E.; Hatton, E.; Joughin, I. Ice velocity of Jakobshavn Isbræ, Petermann Glacier, Nioghalvfjerdsfjorden, and Zachariæ Isstrøm, 2015-2017, from Sentinel 1-a/b SAR imagery. Cryosphere 2018, 12, 2087-2097. [CrossRef]

59. Mouginot, J.; Scheuchl, B.; Rignot, E. Mapping of ice motion in Antarctica using synthetic-aperture radar data. Remote Sens. 2012, 4, 2753-2767. [CrossRef]

60. Wendt, A.; Mayer, C.; Lambrecht, A.; Floricioiu, D. A glacier surge of Bivachny Glacier, Pamir Mountains, observed by a time series of high-resolution digital elevation models and glacier velocities. Remote Sens. 2017, 9, 388. [CrossRef]

61. Torres, R.; Snoeij, P.; Geudtner, D.; Bibby, D.; Davidson, M.; Attema, E.; Potin, P.; Rommen, B.; Floury, N.; Brown, M. GMES Sentinel-1 mission. Remote Sens. Environ. 2012, 120, 9-24. [CrossRef]

62. Drusch, M.; Del Bello, U.; Carlier, S.; Colin, O.; Fernandez, V.; Gascon, F.; Hoersch, B.; Isola, C.; Laberinti, P.; Martimort, P. Sentinel-2: ESA's optical high-resolution mission for GMES operational services. Remote Sens. Environ 2012, 120, 25-36. [CrossRef]

63. Gorelick, N.; Hancher, M.; Dixon, M.; Ilyushchenko, S.; Thau, D.; Moore, R. Google Earth Engine: Planetary-scale geospatial analysis for everyone. Remote Sens. Environ 2017, 202, 18-27. [CrossRef]

64. Nemani, R.; Votava, P.; Michaelis, A.; Melton, F.; Milesi, C. Collaborative supercomputing for global change science. EOS 2011, 92, 109-110. [CrossRef]

65. Bermudez, I.; Traverso, S.; Mellia, M.; Munafo, M. Exploring the cloud from passive measurements: The Amazon AWS case. In Proceedings of the 2013 Proceedings IEEE INFOCOM, Turin, Italy, 14-19 April 2013; pp. 230-234.

66. Kumar, L.; Mutanga, O. Google Earth Engine applications since inception: Usage, trends, and potential. Remote Sens. 2018, 10, 1509. [CrossRef]

67. Hansen, M.C.; Potapov, P.V.; Moore, R.; Hancher, M.; Turubanova, S.A.; Tyukavina, A.; Thau, D.; Stehman, S.; Goetz, S.J.; Loveland, T.R. High-resolution global maps of 21st-century forest cover change. Science 2013, 342, 850-853. [CrossRef]

68. Xiong, J.; Thenkabail, P.S.; Gumma, M.K.; Teluguntla, P.; Poehnelt, J.; Congalton, R.G.; Yadav, K.; Thau, D. Automated cropland mapping of continental Africa using Google Earth Engine cloud computing. ISPRS J. Photogramm. Remote Sens. 2017, 126, 225-244. [CrossRef]

69. Liu, X.; Hu, G.; Chen, Y.; Li, X.; Xu, X.; Li, S.; Pei, F.; Wang, S. High-resolution multi-temporal mapping of global urban land using Landsat images based on the Google Earth Engine Platform. Remote Sens. Environ. 2018, 209, 227-239. [CrossRef]

70. Zeltner, N. Using the Google Earth Engine for Global Glacier Change Assessment; Geographisches Institut der Universität Zürich: Zürich, Switzerland, 2016. Available online: https://uzb.swisscovery.slsp.ch/discovery / fulldisplay?docid=alma9901118602902 05508\&context=L\&vid=41SLSP_UZB:UZB\&lang=de\&search_scope=DN_and_CI\&adaptor=Local\%20Search\%20Engine\&tab= 41SLSP_UZB_DN_and_CI\&query=any, contains,Using\%20the\%20Google\%20Earth\%20Engine\%20for\%20Global\%20Glacier\% 20Change\%20Assessment\&offset $=0$ (accessed on 15 February 2021).

71. Unger-Shayesteh, K.; Vorogushyn, S.; Farinotti, D.; Gafurov, A.; Duethmann, D.; Mandychev, A.; Merz, B. What do we know about past changes in the water cycle of Central Asian headwaters? A review. Glob. Planet. Chang. 2013, 110, 4-25. [CrossRef]

72. Immerzeel, W.; Bierkens, M. Asia's water balance. Nat. Geosci. 2012, 5, 841-842. [CrossRef]

73. Guo, W.; Liu, S.; Xu, J.; Wu, L.; Shangguan, D.; Yao, X.; Wei, J.; Bao, W.; Yu, P.; Liu, Q. The second Chinese glacier inventory: Data, methods and results. J. Glaciol. 2015, 61, 357-372. [CrossRef]

74. Zhang, Z.; Liu, S.; Wei, J.; Xu, J.; Guo, W.; Bao, W.; Jiang, Z. Mass change of glaciers in Muztag Ata-Kongur Tagh, Eastern Pamir, China from 1971/76 to 2013/14 as derived from remote sensing data. PLoS ONE 2016, 11, e0147327. [CrossRef] [PubMed]

75. RIEGL Laser Measurement Systems. 3D Terrestrial Laser Scanner Riegl VZ®-4000/Riegl VZ®-6000 General Description and Data Interfaces; RIEGL Laser Measurement Systems: Horn, Austria, 2014.

76. DAVIS Instruments. Wireless Vantage Pro2 ${ }^{\mathrm{TM}} \mathcal{E}_{\text {Vantage Pro2 }}^{\mathrm{TM}}$ Plus Stations; DAVIS Instruments: Hayward, CA, USA, 2020.

77. Kääb, A. Monitoring high-mountain terrain deformation from repeated air-and spaceborne optical data: Examples using digital aerial imagery and ASTER data. ISPRS J. Photogramm. Remote Sens. 2002, 57, 39-52. [CrossRef]

78. Debella-Gilo, M.; Kääb, A. Locally adaptive template sizes for matching repeat images of Earth surface mass movements. ISPRS J. Photogramm. Remote Sens. 2012, 69, 10-28. [CrossRef]

79. Pfeffer, W.T.; Arendt, A.A.; Bliss, A.; Bolch, T.; Cogley, J.G.; Gardner, A.S.; Hagen, J.-O.; Hock, R.; Kaser, G.; Kienholz, C. The Randolph Glacier Inventory: A globally complete inventory of glaciers. J. Glaciol. 2014, 60, 537-552. [CrossRef]

80. Fey, C.; Wichmann, V. Long-range terrestrial laser scanning for geomorphological change detection in alpine terrain-handing uncertainties. Earth Surf. Process. Landf. 2017, 42, 789-802. [CrossRef]

81. Gabbud, C.; Micheletti, N.; Lane, S.N. Lidar measurement of surface melt for a temperate Alpine glacier at the seasonal and hourly scales. J. Glaciol. 2015, 61, 963-974. [CrossRef]

82. Revuelto, J.; López-Moreno, J.I.; Azorin-Molina, C.; Zabalza, J.; Arguedas, G.; Vicente-Serrano, S.M. Mapping the annual evolution of snow depth in a small catchment in the Pyrenees using the long-range terrestrial laser scanning. J. Maps 2014, 10, 379-393. [CrossRef] 
83. Sund, M.; Eiken, T.; Hagen, J.O.; Kääb, A. Svalbard surge dynamics derived from geometric changes. Ann. Glaciol. 2009, 50, 50-60. [CrossRef]

84. China Meteorological Data Network. Available online: http:/ / data.cma.cn/ (accessed on 15 February 2021).

85. Fountain, A.G.; Walder, J.S. Water flow through temperate glaciers. Rev. Geophys. 1998, 36, 299-328. [CrossRef]

86. Kamb, B. Glacier surge mechanism based on linked cavity configuration of the basal water conduit system. J. Geophys. Res. Solid Earth 1987, 92, 9083-9100. [CrossRef]

87. Cowton, T.; Nienow, P.; Sole, A.; Wadham, J.; Lis, G.; Bartholomew, I.; Mair, D.; Chandler, D. Evolution of drainage system morphology at a land-terminating Greenlandic outlet glacier. J. Geophys. Res. Earth Surf. 2013, 118, 29-41. [CrossRef]

88. Su, B.; Li, L.Z.; Zhang, M.; Guo, R.; Sun, M.; Che, Y.; Ying, X. A comparative study on mass balance between the continental glaciers and the temperate glaciers: Taking the typical glaciers in the Tianshan Mountains and the Alps as examples. J. Glaciol. Geocryol. 2015, 37, 1131-1140. [CrossRef]

89. Luo, Y.; Li, L.H.; Li, Z.Q. The relationship between the mass balances and meteorological factors at the glacier of No. 72, Qingbingtan, Shenqi Peak, Tuomuer Area. J. Arid Land Resour. Environ. 2012, $26,5$.

90. Li, N. Physical Geography, 2nd ed.; Science Press: Beijing, China, 2001; pp. 89-90.

91. Flowers, G.E. Modelling water flow under glaciers and ice sheets. Proc. Math Phys. Eng. Sci. 2015, 471, 20140907. [CrossRef] 